OPEN ACCESS

Edited by:

Cristina Santin,

Swansea University, United Kingdom

Reviewed by:

Sasha Wagner

Northeastern University, United States Melissa R. A. Pingree,

University of Idaho, United States

${ }^{*}$ Correspondence:

Omar R. Harvey

omar.harvey@tcu.edu

Specialty section: This article was submitted to Biogeoscience, a section of the journal

Frontiers in Earth Science

Received: 04 December 2017 Accepted: 18 April 2018 Published: 08 May 2018

Citation:

Stuart JM, Anderson R, Lazzarino P, Kuehn KA and Harvey OR (2018) Physical Processes Dictate Early Biogeochemical Dynamics of Soil Pyrogenic Organic Matter in a Subtropical Forest Ecosystem. Front. Earth Sci. 6:52. doi: 10.3389/feart.2018.00052

\section{Physical Processes Dictate Early Biogeochemical Dynamics of Soil Pyrogenic Organic Matter in a Subtropical Forest Ecosystem}

\author{
Jason M. Stuart ${ }^{1}$, Russell Anderson ${ }^{1}$, Patrick Lazzarino ${ }^{2}$, Kevin A. Kuehn ${ }^{3}$ and \\ Omar R. Harvey ${ }^{1,2 *}$
}

'Department of Geography and Geology, University of Southern Mississippi, Hattiesburg, MS, United States, ${ }^{2}$ School of Geology, Energy and the Environment, Texas Christian University, Fort Worth, TX. United States, ${ }^{3}$ Department of Biological Sciences, University of Southern Mississippi, Hattiesburg, MS, United States

Quantifying links between pyOM dynamics, environmental factors and processes is central to predicting ecosystem function and response to future perturbations. In this study, changes in carbon (TC), nitrogen (TN), pH, and relative recalcitrance $\left(R_{50}\right)$ for pineand cordgrass-derived pyOM were measured at 3-6 weeks intervals throughout the first year of burial in the soil. Objectives were to (1) identify key environmental factors and processes driving early-stage pyOM dynamics, and (2) develop quantitative relationships between environmental factors and observed changes in pyOM properties. The study was conducted in sandy soils of a forested ecosystem within the Longleaf pine range of the United States with a focus on links between changes in pyOM properties, fire history $(F H)$, cumulative precipitation $\left(P_{\text {cum }}\right)$, average temperature $\left(T_{\text {avg }}\right)$ and soil residence time (SRT). $P_{\text {cum }}, S R T$ and $T_{\text {avg }}$ were the main factors controlling TC and TN accounting for $77-91 \%$ and $64-96 \%$ of their respective variability. Fire history, along with $P_{\text {cum }}, S R T$ and $T_{\text {avg }}$, exhibited significant controlling effects on $p y \mathrm{OM} \mathrm{pH}$ and $R_{50}-$ accounting for $48-91 \%$ and $88-93 \%$ of respective variability. Volatilization of volatiles and leaching of water-soluble components (in summer) and the sorption of exogenous organic matter (fall through spring) were most plausibly controlling pyOM dynamics in this study. Overall, our results point to climatic and land management factors and physicochemical process as the main drivers of pyOM dynamics in the pine ecosystems of the Southeastern US.

Keywords: pyOM dynamics, fire-derived soil carbon, forest soils, recalcitrance, priming effects

\section{INTRODUCTION}

Current evidence suggests that despite a relatively small annual global production rate (40-259 Gt/yr; Bird et al., 2015; Santin et al., 2015), carbon in the fire-derived/pyrogenic organic matter ( $p y \mathrm{OM})$ pool accounts for a significant quantity $(2-45 \%)$ of the total organic carbon in terrestrial systems (Skjernstad et al., 1999; Skjemstad et al., 2002; Lehmann et al., 2008; Reisser et al., 2016). There is fairly widespread consensus that the significant quantity of terrestrial carbon held in the $p y \mathrm{OM}$ pool is largely attributable to a comparatively higher innate resistance/recalcitrance to abiotic/biotic degradation and, longer turnover times of pyrogenic carbon compared to its non-pyrogenic counterpart (Schmidt and Noack, 2000; Hammes et al., 2008). For example, 
turnover times for pyrogenic carbon are on the order of decades to thousands of years, compared to a few years for its nonpyrolysed counterpart (Hammes et al., 2008; Liang et al., 2008; Carvalhais et al., 2014; de la Rosa et al., 2018).

The recognition of $p y \mathrm{OM}$ being relatively more resistant to abiotic and biotic transformation has led to increased interest in the global pyOM pool as a potential carbon sink and carbon sequestration strategy (Lehmann et al., 2006). Current estimates for carbon sequestration potential in the pyOM pool are as high as $9.5 \times 10^{9}$ tons $\mathrm{C} / \mathrm{yr}$-comparable to estimated carbon emission from fossil fuel burning (9.1 $\times 10^{9}$ tons $\mathrm{C} / \mathrm{yr}$; Lehmann et al., 2006). However, it is now well-known that this sequestration potential will vary with pyOM composition/properties as well as field/environmental conditions. The composition/properties of pyOM have been extensively studied and are known to be a heterogeneous mix of thermally-altered carbon-, hydrogen-, nitrogen-, oxygen, and sulfur-containing organic structures with the degrees of heterogeneity or thermal alteration varying systematically across feedstock chemistry and pyrolysis conditions (e.g., Zimmerman, 2010; Harvey et al., 2012). Increasing degrees of thermal alteration favor increasingly condensed carbonand/or nitrogen-rich structures of higher innate environmental recalcitrance/stability (Knicker et al., 2008; Knicker, 2010; Zimmerman, 2010; Harvey et al., 2012).

Current understanding of the impact of variations in environmental conditions on pyOM behavior is far less clear than that for feedstock chemistry or pyrolysis conditions. Results on the biogeochemical trajectory of key pyOM properties and, most importantly, the environmental factors driving that trajectory are still unclear. For example, Mukherjee et al. (2014) reported increases of up to 124,143 , and $43 \%$ in pyOM-associated carbon, nitrogen and exchange capacity, respectively-after burying different pyOMs for 15 months in two distinct soils (a sandy Entisol used for agriculture and a forested Spodosol) in Florida. The observed differences in pyOM behavior were attributed to differences in soil composition and structure. In contrast, while Sorrenti et al. (2016) and de la Rosa et al. (2018) observed increases in pyOM-associated nitrogen (fourfold) after soil burial of pyOM for 24-48 months, they both reported decreases in pyOM-associated carbon (11-27\%). Both studies were conducted in inceptisols (in the case of Sorrenti et al. (2016) - a sandy loam in Italy and in the case of de la Rosa et al.- a sandy clay loam in Spain). Except noting that hydrologic properties of $p y \mathrm{OM}$ were linked to surface changes induced by environmental exposure, Sorrenti et al. (2016) did not discuss specific environmental factors driving observed changes. On the other hand, de la Rosa et al. (2018) noted climatic conditions (in particular rainfall and temperature) and soil characteristics as the key drivers of the observed changes in pyOM-associated carbon and nitrogen.

Whilst it is intuitive-and of great qualitative value-that environmental factors such as ecosystem type, soil properties, temperature, nutrient availability and moisture conditions drives pyOM dynamics (Cheng et al., 2008; O’Neill et al., 2009; Khodadad et al., 2011; Bird et al., 2015); quantitative assessments of the individual and interactive contributions of these factors are necessary for predicting the behavior and ecosystem value of pyOM over time and space. Such assessments remain sparse and, to our knowledge, are currently exclusively obtained via metaanalysis type studies. Recent meta-analytical studies directly addresses important environmental factors driving; (1) the environmental persistence of $p y \mathrm{OM}$, its priming effects on native soil organic matter (SOM; Wang et al., 2016) and (2) its global distribution in carbon stocks (Reisser et al., 2016). Wang et al. (2016) found that for a given pyOM, experimental duration (soil residence time, SRT) and soil clay content controlled the degradation rate of $p y \mathrm{OM}$, and its priming effect-with higher pyOM degradation rates and positive $p y \mathrm{OM}$ priming of native SOM favored at $S R T<0.5$ years and soil clay contents $\leq 9 \%$. Reisser et al. (2016) found that, globally, the largest pyOMassociated carbon stocks generally occurred in areas of warmer climates $\left(\geq 10^{\circ} \mathrm{C}\right)$ and soils having high clay contents $(>50 \%)$ and/or $\mathrm{pH}>7$. Higher $p y \mathrm{OM}$-associated carbon in warmer climates was attributed to higher temperature-promoted biomass production and fire probability; and in high clay content, high $\mathrm{pH}$ soils due to protection via organo-mineral interactions leading to less pyOM degradation (Reisser et al., 2016).

As demonstrated through the work of both Wang et al. (2016) and Reisser et al. (2016), global meta-analysis-type studies can provide valuable insights into the environmental factors that drive pyOM dynamics at the global scale. It is also equally important to recognize that such studies represent the global/onaverage case and are not necessarily directly transferrable (or downscalable) to explaining $p y \mathrm{OM}$ dynamics at local or regional scales. That is, factors determined to be driving pyOM dynamics at the global scale may not necessarily explain variability at finer scales-especially, when spatial and/or temporal variability in potential environmental drivers differ from that captured in global assessment.

It is reasonable to expect spatial variability in the (i) fire and landuse, (ii) climatic, and (iii) pedogenic drivers of pyOM dynamics, identified by Reisser et al. (2016), at the local and regional scales. With season-to-season variability in rainfall and temperature, changes in landuse and land/fire management, as well as projected climate shifts, environmental drivers of $p y \mathrm{OM}$ dynamics can also be expected to change on short- and longterm temporal scales. For example, with climate change projected to induce regional shifts in temperatures and precipitation, the fire regimes, the amount of $p y \mathrm{OM}$ produced, the soil moisture, biota, and consequently pyOM biogeochemical cycling are expected to be altered (Flannigan et al., 2000; Santin et al., 2015). Identifying region specific drivers of pyOM dynamics and developing quantitative relationships between them and the properties and processes they drive are central to predicting impacts of environmental change on ecosystem functions such as carbon sequestration and nutrient cycling.

In this study, we tracked early dynamics of $p y \mathrm{OM}$ from two isotopically distinct sources at 3-6 weeks intervals throughout the first year of burial in coarse textured ultisols located in a forested ecosystem within the Longleaf pine range of the Southeastern United States. The objectives of the study were to (1) identify key environmental factors and processes driving early-stage biogeochemical alteration in $p y \mathrm{OM}$ in such an ecosystem, and 
(2) develop quantitative relationships between environmental factors and observed changes in $p y \mathrm{OM}$ properties to explain early-stage dynamics of $p y \mathrm{OM}$. Focus was placed specifically on the relationship between fire history ( $F H$; burnt vs. unburnt), cumulative precipitation $\left(P_{\text {cum }}\right)$, average temperature $\left(T_{\text {avg }}\right)$, soil residence time $(S R T)$ and early-stage temporal variability in pyOM-associated carbon, $p y \mathrm{OM}$-associated nitrogen, $p y \mathrm{OM} \mathrm{pH}$ and $p y \mathrm{OM}$ stability/degradability. The underlying hypothesis was that in its early stages, $p y \mathrm{OM}$ dynamics in sandy-textured (low CEC, low organic matter) soils is analogous to initial stages of soil formation whereby climatic effects (e.g., precipitation and temperature) and the innate properties of the parent material (rock type in the case of soils; in our case, pine- vs. cordgrassderived pyOM) dictates outcome.

\section{MATERIALS AND METHODS}

\section{Study Site, Sampling, and Soil Description}

The study was conducted at the Lake Thoreau Environmental Center (LTEC; $31.3466^{\circ} \mathrm{N}, 89.4223^{\circ} \mathrm{W}$ ), a 121-hectare facility owned and operated by The University of Southern Mississippi in a manner that parallels historic and current forest management practices across the Southeastern US. The LTEC is located within the pine-belt of Mississippi and the wider Longleaf pine range of the Southeastern United States. It is representative of the region in terms of vegetative cover ( $\sim 52 \%$ pine forest), fire management ( 2 year prescribed-burning cycle vs. no burning), surface soils (coarse textured ultisols formed from coastal plain sediments; Soil Survey Staff, 2018), mean annual temperature $\left(15-21^{\circ} \mathrm{C}\right.$; Markewitz et al., 2002), mean annual rainfall/precipitation (1,020-1,520 mm; Markewitz et al., 2002) and Koppen-Geiger Climate Classification (humid subtropical; Kottek et al., 2006). Average seasonal temperatures at the LTEC are $32.1,25.5,16.2$, and $25.2^{\circ} \mathrm{C}$ for the summer, fall, winter, and spring seasons, respectively with average monthly precipitation values for the same seasons of 112, 105, 139, and $147 \mathrm{~mm}$, respectively.

A total of six sampling locations, along two converging transects, were selected for use in this study (Figure 1). Four sampling locations were in an area (herein referred to as the Burnt Zone) with a consistent two-year prescribed burning cycle since the mid 1960's; the most recent burn occurring in January of 2014-prior to the start of the study in the Summer of 2014 (May 31, 2014). The remaining two sampling locations were in an area (herein referred to as the unburnt zone) that has no history of ever being burnt or systematically managed in the last 50 years-besides infrequent grazing from miniature cattle in a small subsection. Sampling locations in the burnt zone are designated with a "B" and those in the unburnt zone are designated with a " $U$ " (see Figure $\mathbf{1}$ for complete sampling designations). At the time of the study, the sample sites within the unburnt zone were not being grazed and had very heavily vegetated understories and shrub layers as well as thick litter layers on the forest floor.

Elevation for the study area varied from 88 to $100 \mathrm{~m}$ above sea level with overall downhill sloping from NE to SW (i.e., from $\mathrm{B} 4$ to $\mathrm{B} 1$ ). Soils at the study site are alluvial in origin and with the exception of B2, were mapped in the US Soil Survey as being from the Freestone-McLaurin-Susquehanna association. The Freestone-McLaurin-Susquehanna association is characterized by a moderately well-drained upper profiletypical of the predominantly coarse-textured ultisols found in the Long leaf pine range. Soils at sampling location B2 were mapped as the Prentiss series (also typical of the region) and comprising also of moderately well-drained upper profile. The textures of soils in the upper $10 \mathrm{~cm}$ at the sample locations were determined via the hydrometer method of Gee and Bauder (1986) to be sandy clay loam (B1, B2, B3, U1, U2) or borderline sandy clay loam/clay loam (B4; Supplementary Figure 1).

At each of the six sampling location, samples of pinederived (P, Pinus taeda) and cordgrass-derived (CG, Spartina alterniflora) pyOM were placed in polypropylene litterbags and buried in a gridded design at a depth of $\sim 8 \mathrm{~cm}$ below the soil surface (Supplementary Figure 2). A total of $11 \mathrm{P}$ and 11 CG pyOM-containing litterbags were buried at each sampling location. One litterbag each of $\mathrm{P}$ and $\mathrm{CG}$ pyOM were removed on each sampling excursion, which occurred at 21, 42, 63, 84, $105,126,147,217,294,322$, and 350 days after burial. Samples collected on each excursion were split 2:1, with two-thirds of each sample being dried $\left(75^{\circ} \mathrm{C}\right.$ for $\left.24 \mathrm{~h}\right)$ and used for immediate analysis of $\mathrm{pH}$, electrical conductivity (EC), relative recalcitrance $\left(R_{50}\right)$, total carbon content and total nitrogen content, while one-third of the sample was frozen and subsampled for use in ergosterol, and $\delta^{13} \mathrm{C}$ and $\delta^{15} \mathrm{~N}$ isotopic analysis.

\section{Preparation of pyOM}

Pine-derived $p y \mathrm{OM}$ was produced from pine needles collected from the study site, while cordgrass-derived $p y \mathrm{OM}$ was produced from cordgrass straw collected from USM's Gulf Coast Research Laboratory. Prior to pyrolysis, needles and grass were dried at $60^{\circ} \mathrm{C}$ to constant weight and cut into $\sim 2 \mathrm{~cm}$ pieces. Pyrolysis of plant material was performed in a muffle furnace (ramp rate $=25^{\circ} \mathrm{C} / \mathrm{min}$ ) under oxygen-limited conditions at $450^{\circ} \mathrm{C}$ for a total of $1 \mathrm{~h}$. The $450^{\circ} \mathrm{C}$ was representative of average temperature conditions for a typical vegetation fire in the southeastern United States (Alexis et al., 2007). Upon cooling and removal from the furnace, the $p y \mathrm{OM}$ material was separated into a fine $(<250 \mu \mathrm{m})$ and a coarse $(250-500 \mu \mathrm{m})$ fraction. Approximately $1.5 \mathrm{~g}$ of the coarse pyOM material was placed into litterbags ( 8 $\times 8 \mathrm{~cm}$ ). The litterbags used were made from needle-punched polypropylene material with apparent openings of $210 \mu \mathrm{m}$ (small enough to contain the coarse fraction of the $p y \mathrm{OM}$, yet large enough to allow environmental interaction with the $p y \mathrm{OM})$.

\section{Post-burial pyOM and Soil Analysis}

Pyrogenic organic matter collected on each sampling excursion was analyzed for total carbon content (TC), total nitrogen (TN), $\mathrm{pH}$ and relative recalcitrance $\left(R_{50}\right)$. Samples from selected excursions were analyzed for fungal ergosterol, base-extractable organic carbon (BEOC) and $\delta^{13} \mathrm{C}$ and $\delta^{15} \mathrm{~N}$ isotopic signature.

Carbon and nitrogen content was determined in triplicate by combustion elemental analysis (Costech elemental combustion analyzer) using 2-3 mg of pyOM tightly wrapped in tin capsules 


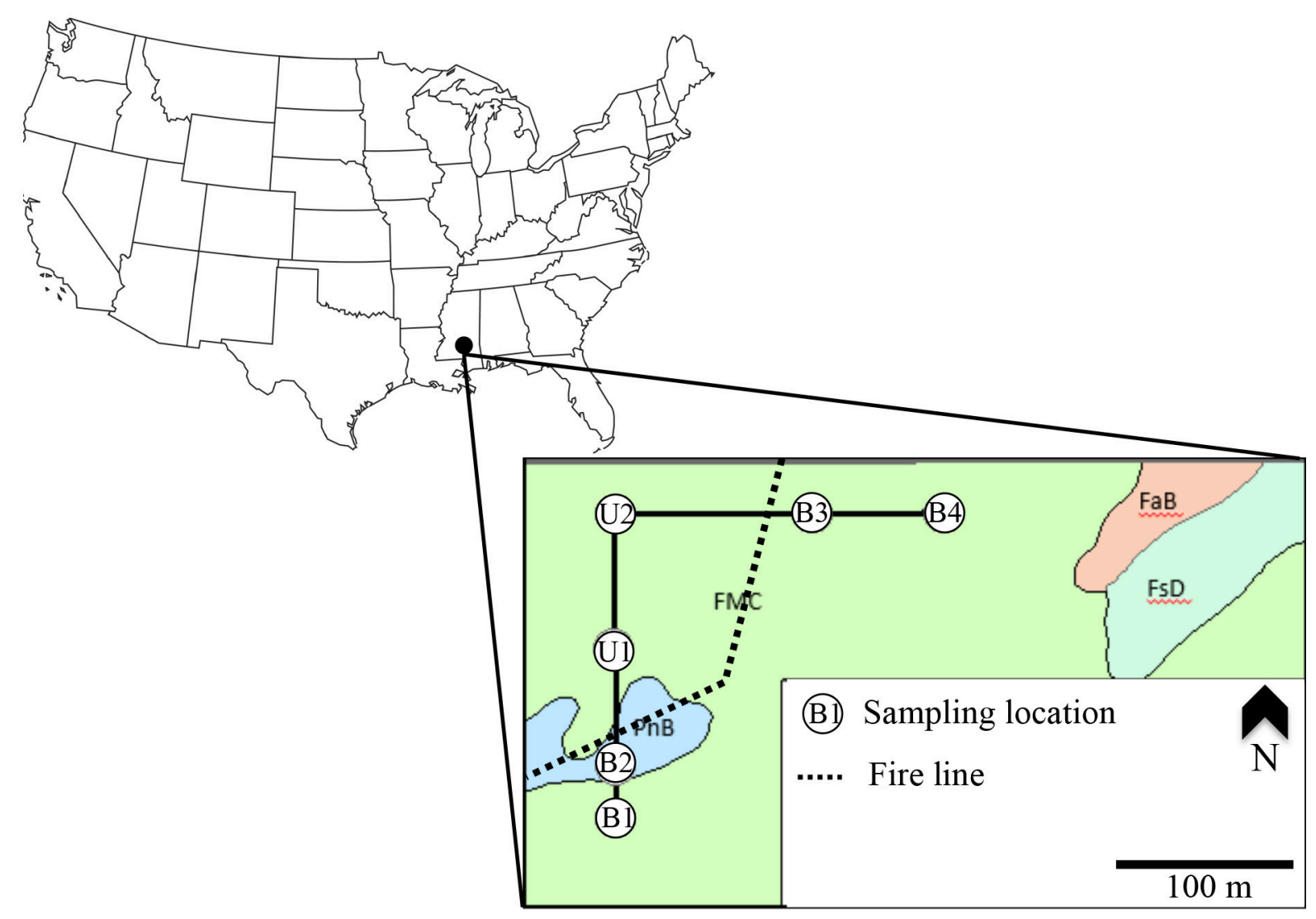

FIGURE 1 | Map of study area showing sampling locations, fire line separating the unburnt and burnt zone, and map unit level classification of soils per US Soil Survey (FMC, Freestone-McLaurin-Susquehanna association; PnB, Prentiss fine sandy loam, 2-5\% slope; FaB, Faulkner silt loam, 2-5\% slope; Soil Survey Staff, 2018).

combusted and compared to acetanilide as a standard (Sarkhot et al., 2012).

Base-extractable organic carbon (BEOC) of $p y \mathrm{OM}$ samples was determined using UV-visible spectrophotometry. Between 150 and $151 \mathrm{mg}$ of pyOM was placed in $30 \mathrm{ml}$ of $0.5 \mathrm{M} \mathrm{NaOH}$ solution before being heated for $2 \mathrm{~h}$ at $80^{\circ} \mathrm{C}$. After heating, the pyOM: $\mathrm{NaOH}$ suspension was cooled, filtered $(0.2 \mu \mathrm{m})$ and the absorbance measured at $365 \mathrm{~nm}$ then compared to a 4 point standard curve of absorbance vs. dissolved organic carbon content from heated-persulfate oxidation method (Shimadzu Scientific Instruments, Columbia, Maryland; Raimbault et al., 1999; Harvey et al., 2009).

For pyOM pH and EC, $5 \mathrm{ml}$ of de-ionized water was mixed with $50 \mathrm{mg}$ of sample, creating a 1:100 pyOM: water suspension. This solution was allowed to equilibrate for $12 \mathrm{~h}$ before measuring the $\mathrm{pH}$ and $\mathrm{EC}$ of the extractant (Accumet $\mathrm{pH} / \mathrm{EC}$ submersible probe).

Relative recalcitrance of the pyOM was determined by thermogravimetric analysis (TGA; SDTQ600, TA Instruments, New Castle, DE) and the use of the $R_{50}$ index as described by Harvey et al. (2012). Thermal analysis began at an oven temperature of $20^{\circ} \mathrm{C}$, increasing at a ramp rate of $10^{\circ} \mathrm{C}$ per minute until $700^{\circ} \mathrm{C}$, at which point no further weight loss was observed. The $R_{50}$ value of the $p y \mathrm{OM}$ is a measure of the innate resistance of the pyOM material to abiotic and biotic oxidation, and was calculated as:

$$
R_{50}=\frac{T_{50, p y O M}}{T_{50, \text { graphite }}}
$$

where $T_{50, p y O M}$ and $T_{50 \text {,graphite }}$ are the temperature values corresponding to $50 \%$ oxidation of $p y \mathrm{OM}$ material and graphite (<149 $\mu \mathrm{m}$, purity 99.9995\%; Alfa Aesar, Ward Hill, MA), respectively, and were obtained via use of TGA mentioned above.

The fungal biomass associated with $p y \mathrm{OM}$ samples were estimated using ergosterol concentrations (Kuehn et al., 2011). Ergosterol was extracted from pyOM samples ( $\sim 60 \mathrm{mg}$ ) by refluxing in alcoholic $\mathrm{KOH}(4 \% \mathrm{KOH}$ in $95 \%$ methanol) for $30 \mathrm{~min}$. The resultant extract was partitioned into $n$-pentane and evaporated to dryness under a stream of nitrogen gas. Ergosterol in dried samples was then re-dissolved by sonication in $0.5 \mathrm{ml}$ of methanol and stored, tightly capped, in $1.5 \mathrm{ml}$ screw cap high pressure liquid chromatography (HPLC) vials at $\sim 20^{\circ} \mathrm{C}$ until analyzed. Separation and analysis of ergosterol was done using HPLC according to procedures from Kuehn et al. (2011).

Carbon and nitrogen $\left(\delta^{13} \mathrm{C}\right.$ and $\left.\delta^{15} \mathrm{~N}\right)$ isotopic signature of the $p y \mathrm{OM}$ were determined by EA-IRMS using 2-3 mg of sample 
and an elemental analyzer (EA) interfaced to a Thermo-Electron Delta $\mathrm{V}$ Advantage isotope ratio mass spectrometer (IRMS). Values for $\delta^{13} \mathrm{C}$ were reported relative to the Vienna PeeDee Belemnite standard and values for $\delta^{15} \mathrm{~N}$ to atmospheric nitrogen.

In addition to pyOM, soils were collected (to a depth of $\sim 3 \mathrm{~cm}$ ) from directly beneath the litterbags on each of the following sampling excursions. The collected soil samples were air-dried to constant weight, grounded to $<2 \mathrm{~mm}$ and used for soil $\mathrm{pH}$ and soil organic carbon (SOC) analyses. Soil $\mathrm{pH}$ and SOC was determined using the same procedures as described above for pyOM albeit samples for SOC analyses were done using $20 \mathrm{mg}$ of sample. It is worth noting that in these soils TC $=$ SOC because of the lack of inorganic carbon-verified by the lack of fizzing in response to $\mathrm{HCl}$ additions and supported by the acidic soil $\mathrm{pH}$.

\section{Precipitation and Temperature Data}

The LTEC maintains a weather station $(\sim 600 \mathrm{~m}$ west of the study site) with research grade sensors for monitoring precipitation (Tipping bucket rain gauge; model: TE525WSTexas Electronics) and temperature (HygroClip2 HC2s3Rotronic Instrument) as well as other climatic parameters (relative humidity, barometric pressure, solar irradiance and wind speed/direction) on 1-min temporal scales. For this study, 1-min averaged precipitation and temperature data were aggregated to obtain daily precipitation and average air temperatures for every day of the study. Daily values were further aggregated through addition or averaging to obtain cumulative precipitation $\left(P_{\text {cum }}\right)$ and average maximum daily temperature $\left(T_{\text {avg }}\right)$, respectively for each sampling day. It is these latter $P_{\text {cum }}$ and $T_{\text {avg }}$ that are utilized in all our analyses.

\section{Data Analysis and Modeling}

Data analysis was conducted in two phases. The first phase of analysis was executed using two-way analysis of variance and was focused on assessing the relative importance of time (as SRT) and sample site in driving observed changes in $p y \mathrm{OM}$ properties of both pine- and cordgrass-derived $p y \mathrm{OM}$ within a given fire history/zone (i.e., burnt vs. unburnt). The goal of this initial analysis was to screen if measured changes in pyOM properties at the study site were controlled primarily by temporally- or spatially-driven environmental factors (e.g., soil properties) and, therefore, data within a given fire zone could be aggregated across space or time. Two-way analysis was done using Graphpad Prism (version 7.0).

The second phase of data analysis was executed using generalized linear modeling (GLM) and was focused on identifying and then modeling statistically significant $(p<0.05)$ main and/or interactive effects of environmental co-factors (soil residence time, SRT (in days); cumulative precipitation, $P_{\text {cum }}$ (in $\mathrm{mm}$ ); average maximum daily temperature, $T_{\text {avg }}\left(\right.$ in ${ }^{\circ} \mathrm{C}$ ); and fire history, $F H$; burnt vs. unburnt) on changes in $p y \mathrm{OM}$ properties (TC, TN, $\mathrm{pH}$, and $R_{50}$ ). Three initial GLM models were fitted to respective datasets for cordgrass- and pine-derived $p y \mathrm{OM}$ :

1) A main-effects only model with a linear predictor component of the form, $Y=\beta_{0}+\beta_{1}(S R T)+\beta_{2}\left(P_{\text {cum }}\right)+\beta_{3}\left(T_{\text {avg }}\right)+$ $\beta_{4}(F H)+\varepsilon$;
2) An interaction-effects only model with a linear predictor component of the form, $Y=\beta_{0}+\beta_{1}\left(S R T \times P_{\text {cum }}\right)+$ $\beta_{2}\left(S R T \times T_{\text {avg }}\right)+\beta_{3}(S R T \times F H)+\beta_{4}\left(P_{\text {cum }} \times T_{\text {avg }}\right)+$ $\beta_{5}\left(P_{\text {cum }} \times \mathrm{FH}\right)+\beta_{6}\left(T_{\text {avg }} \times F H\right)+\varepsilon$; and

3) A combined-effects model with a linear predictor component of the form, $Y=\beta_{0}+\beta_{1}(S R T)+\beta_{2}\left(P_{\text {cum }}\right)+\beta_{3}\left(T_{\text {avg }}\right)+$ $\beta_{4}(F H) \beta_{5}\left(S R T \times P_{\text {cum }}\right)+\beta_{6}\left(S R T \times T_{\text {avg }}\right)+\beta_{7}(S R T \times F H)+$ $\beta_{8}\left(P_{\text {cum }} \times T_{\text {avg }}\right)+\beta_{9}\left(P_{\text {cum }} \times \mathrm{FH}\right)+\beta_{10}\left(T_{\text {avg }} \times F H\right)+\varepsilon ;$

where, $Y$ is the pyOM property of interest, $\beta_{0}$ is the model intercept; $\beta_{1} \ldots \beta_{n}$ are fitted values for contributions of each predictor to $Y$ and $\varepsilon$ is the error term. Values for $F H$ were set to 1 for burnt zone and 0 for the unburnt zone. Each model was fitted in two iterations with a normal random component and an identity link function. The first iteration involved all possible predictors (as outlined above) while the second iteration involved only predictors that were identified from the first iteration as having significant $\beta_{n}$ values (i.e., $p<0.05$ ). Maineffects, interaction-effects and combined-effects models from the second iteration were compared via ANOVA; with the best model being selected as that with the lowest AIC (Akiake Information Criterion) and best fit/trace $\left(\mathrm{R}^{2}\right)$ to the measured data. All statistical analyses were done using the GLM function from statistical package in R-Gui (R-Core Team, 2017).

\section{RESULTS}

\section{Overall Effects of Time and Space on pyOM Dynamics}

Initial properties of the pine- and cordgrass derived $p y \mathrm{OM}$ are summarized in Table 1. Two-way analysis of variance examining the effect of time and sampling site on changes in pyOM properties indicated that time (SRT) accounted for $80-92 \%$ of total variability in pyOM-associated organic carbon, $38-79 \%$ in pyOM-associated nitrogen and $81-91 \%$ in pyOM pH over the course of the study. By comparison, sampling site accounted for $0.005-2.53,0.08-13$, and $1-3 \%$ of variability in $p y \mathrm{OM}$-associated carbon, nitrogen and $\mathrm{pH}$ respectively. Interactive effects between time and sampling site were also much (4-49 times) lower than time effects alone in all cases; except for TN in the unburnt zone where the effect of time alone and interactive effects were equal (Supplementary Table 1). The much higher variability in pyOM-associated carbon, nitrogen and $\mathrm{pH}$ accounted for by time (compared to location or interactive effects) pointed to temporally variable environmental, rather than location-based, factors being the primary drivers of $p y \mathrm{OM}$ dynamics in this study. This also indicated that in contrast to other studies (Kane et al., 2010; Kasin and Ohlson, 2013), variations in early-stage pyOM dynamics due to location-based parameters such as elevation, soil type and position in landscape would not be important in our study. Of such, properties associated with a given $p y \mathrm{OM}$ source and within a given fire zone could be considered as replicates (i.e., properties at $\mathrm{U} 1$ and $\mathrm{U} 2$ are replicates for unburnt treatment while B1, B2, B3, and B4 are replicates for burnt treatments) and can be spatially-aggregated based on pyOM feedstock and fire history without any significant loss in the amount of variability captured in the study. 
TABLE 1 | Selected properties of pyOM at the time of burial.

\begin{tabular}{|c|c|c|c|c|}
\hline & Total Carbon, $T C_{0}(\%)$ & Total Nitrogen, $T N_{0}(\%)$ & Ash Content (\%) & pH руОм \\
\hline Pine-derived pyOM & $64.0 \pm 1.07$ & $0.67 \pm 0.02$ & 13.8 & $6.25 \pm 0.03$ \\
\hline Cordgrass-derived pyOM & $64.0 \pm 1.64$ & $1.44 \pm 0.01$ & 14.3 & $7.89 \pm 0.12$ \\
\hline
\end{tabular}

\section{Temporal Trends in pyOM-Associated Carbon and Nitrogen}

Spatially-aggregated, temporal trends in relative total carbon and nitrogen content associated with pine- or cordgrass-derived pyOM in the unburnt and burnt zones are presented in Figures 2, 3. Over the study period, carbon content associated with pyOM varied between 0.75 and 1.25 times that of initial values in both fire zones and across both pyOM source. Interestingly, relative changes in carbon content associated with pine-derived $p y \mathrm{OM}$ followed that of cordgrass-derived $p y \mathrm{OM}$ throughout the study irrespective of fire history. Summer was characterized by a continued decrease (15-25\% loss of initial) in $p y \mathrm{OM}$-associated carbon across both $p y \mathrm{OM}$ sources and fire history. Fall through winter was characterized by an apparent re-accumulation of carbon, lost during summer, while spring was characterized by an additional $17-25 \%$ increase in pyOMassociated carbon, relative to the initial carbon content.

Like $p y \mathrm{OM}$-associated carbon, temporal trends in $p y \mathrm{OM}$ associated nitrogen for pine- vs. cordgrass-derived $p y \mathrm{OM}$ were comparable in summer- decreasing slightly to $\sim 0.96$ times the initial (Figure 3). However, thereafter, the dynamics of pyOMassociated nitrogen for pine- and cord-grass derived $p y \mathrm{OM}$ followed very different trajectories within a given fire zone. For pine-derived $p y \mathrm{OM}$, no further changes in associated nitrogen content were observed over fall, winter and spring in either the unburnt or burnt zones. In contrast, for cordgrass-derived pyOM, an increase of up to 1.3 times in initial pyOM-associated nitrogen was observed through Fall, peaking in winter at 1.2-1.3 times initial values and remaining stable thereafter until the end of the study in spring.

Precipitation $\left(P_{\text {cum }}\right)$, soil residence time $(S R T)$, average temperature $\left(T_{a v g}\right)$ and the interaction between $P_{c u m}$ and SRT were found (through GLM analyses) to be the significant ( $p$ $<0.05)$ drivers of relative pyOM-associated carbon content. For observed changes in $p y \mathrm{OM}$-associated nitrogen, significant drivers were $P_{\text {cum }}, S R T$, the interactive effects between $P_{\text {cum }}$ and $S R T$, interactions between $T_{a v g}$ and $S R T$ and that between $T_{a v g}$ and $P_{\text {cum }}$. The final generalized linear model for $p y \mathrm{OM}$ associated organic carbon was,

$T C_{t} / T_{0}=2.84 \times 10^{-4}\left(P_{\text {cum }}\right)-1.64 \times 10^{-3}(S R T)-5.67$ $\times 10^{-3}\left(T_{\text {avg }}\right)+1.11 \times 10^{-6}\left(S R T \times P_{\text {cum }}\right)+1.123$, was applicable across fire history (burnt vs. unburnt zone) and $p y \mathrm{OM}$ source (cordgrass vs. pine), and captured $77-91 \%$ of variability in measured values (Figure 2 and Supplementary Figure 3).

The final models for pyOM-associated nitrogen had the same driving factors/parameters for cordgrass- vs. pine-derived pyOM but different estimates for constants (i.e., $\beta_{\mathrm{i}}$ ). In the case cordgrass-derived $p y \mathrm{OM}$, changes in associated nitrogen in both the burnt and unburnt zone could be modeled as:
$\mathrm{TN}_{\mathrm{t}} / \mathrm{TN}_{0}=-2.62 \times 10^{-2}\left(P_{\text {cum }}\right)+8.31 \times 10^{-2}(\mathrm{SRT})+4.93$ $\times 10^{-6}\left(\operatorname{SRT} \times P_{\text {cum }}\right)-2.65 \times 10^{-3}\left(S R T \times T_{\text {avg }}\right)+8.09 \times$ $10^{-4}\left(P_{\text {cum }} \times T_{\text {avg }}\right)+1.117$, capturing $83-96 \%$ of the observed variability in measured values (Figure 3 and Supplementary Figure 4). In the case of pine-drived pyOM, changes in associated nitrogen could be modeled as:

$\mathrm{TN}_{\mathrm{t}} / \mathrm{TN}_{0}=-8.98 \times 10^{-3}\left(P_{\text {cum }}\right)+2.68 \times 10^{-2}(S R T)+1.87$ $\times 10^{-6}\left(S R T \times P_{\text {cum }}\right)-9.20 \times 10^{-4}\left(S R T \times T_{\text {avg }}\right)+2.95 \times$ $10^{-4}\left(P_{\text {cum }} \times T_{\text {avg }}\right)+1.028$, capturing $64-79 \%$ of the observed variability in measured values (Figure 3 and Supplementary Figure 4).

\section{Temporal Changes in pyOM PH and Stability}

Throughout summer and fall, the $\mathrm{pH}$ of the pine-derived $p y \mathrm{OM}$ remained relatively stable at $6.49 \pm 0.24$ in the burnt and unburnt zones, before decreasing through winter and early spring to $5.42 \pm 0.18$ in the burnt zone and $5.03 \pm 0.10$ in the unburnt zone (Figure 4). As spring progressed, $\mathrm{pH}$ of pinederived $p y \mathrm{OM}$ rebounded to $6.36 \pm 0.14$ by the end of the study on day 350. For cordgrass-derived pyOM, pH decreased with time from $7.89 \pm 0.04$ at the start of the experiment in summer to $5.94 \pm 0.11$ and $4.91 \pm 0.07$ in the burnt and unburnt zone, respectively, by early spring (day 294). As spring progressed, as with pine-derived $p y \mathrm{OM}$, the $\mathrm{pH}$ of cordgrass-derived $p y \mathrm{OM}$ also rebounded-reaching $7.15 \pm 0.10$ in the burnt zone and $5.96 \pm 0.03$ in the unburnt zone by the end of the study on day 350 .

Results from GLM analyses indicated that $T_{\text {avg }}$, its interaction with FH, SRT, and $P_{\text {cum }}$, and the interaction between $P_{\text {cum }}$ and $S R T$ were the major factors driving observed changes in the $\mathrm{pH}$ of both cordgrass- and pine-derived pyOM. For cordgrass-derived pyOM the observed changes in both the unburnt and burnt zone could be modeled as;

$\mathrm{pH}_{\text {pyOM }}=3.05 \times 10^{-1}\left(T_{\text {avg }}\right)+1.68 \times 10^{-2}\left(\mathrm{FH} \times \mathrm{T}_{\text {avg }}\right)+1.52$ $\times 10^{-5}\left(S R T \times P_{\text {cum }}\right)+1.40 \times 10^{-3}\left(S R T \times T_{\text {avg }}\right)-6.60 \times 10^{-4}$ $\left(P_{\text {cum }} \times T_{\text {avg }}\right)$, while changes in $\mathrm{pH}$ for the pine-derived $p y \mathrm{OM}$ could be modeled as;

$\mathrm{pH}_{\text {pyOM }}=1.46 \times 10^{-1}\left(T_{\text {avg }}\right)-3.67 \times 10^{-3}\left(\mathrm{FH} \times \mathrm{T}_{\text {avg }}\right)+$ $4.35 \times 10^{-6}\left(S R T \times P_{\text {cum }}\right)+5.55 \times 10^{-4}\left(S R T \times T_{\text {avg }}\right)-2.21$ $\times 10^{-4}\left(P_{\text {cum }} \times T_{\text {avg }}\right)+2.699$. The models accounted for $87-$ 94 and $48-61 \%$ of the variability observed across fire history in cordgrass- and pine-derived pyOM, respectively (Supplementary Figure 5).

Relative recalcitrance/stability, $R_{50}$, values of the pine- and cordgrass-derived $p y \mathrm{OM}$ are shown in Figure 5. These values showed an initial difference in the recalcitrance of pine- and cordgrass-derived $p y \mathrm{OM}$, with $R_{50}$ values starting at 0.524 and 

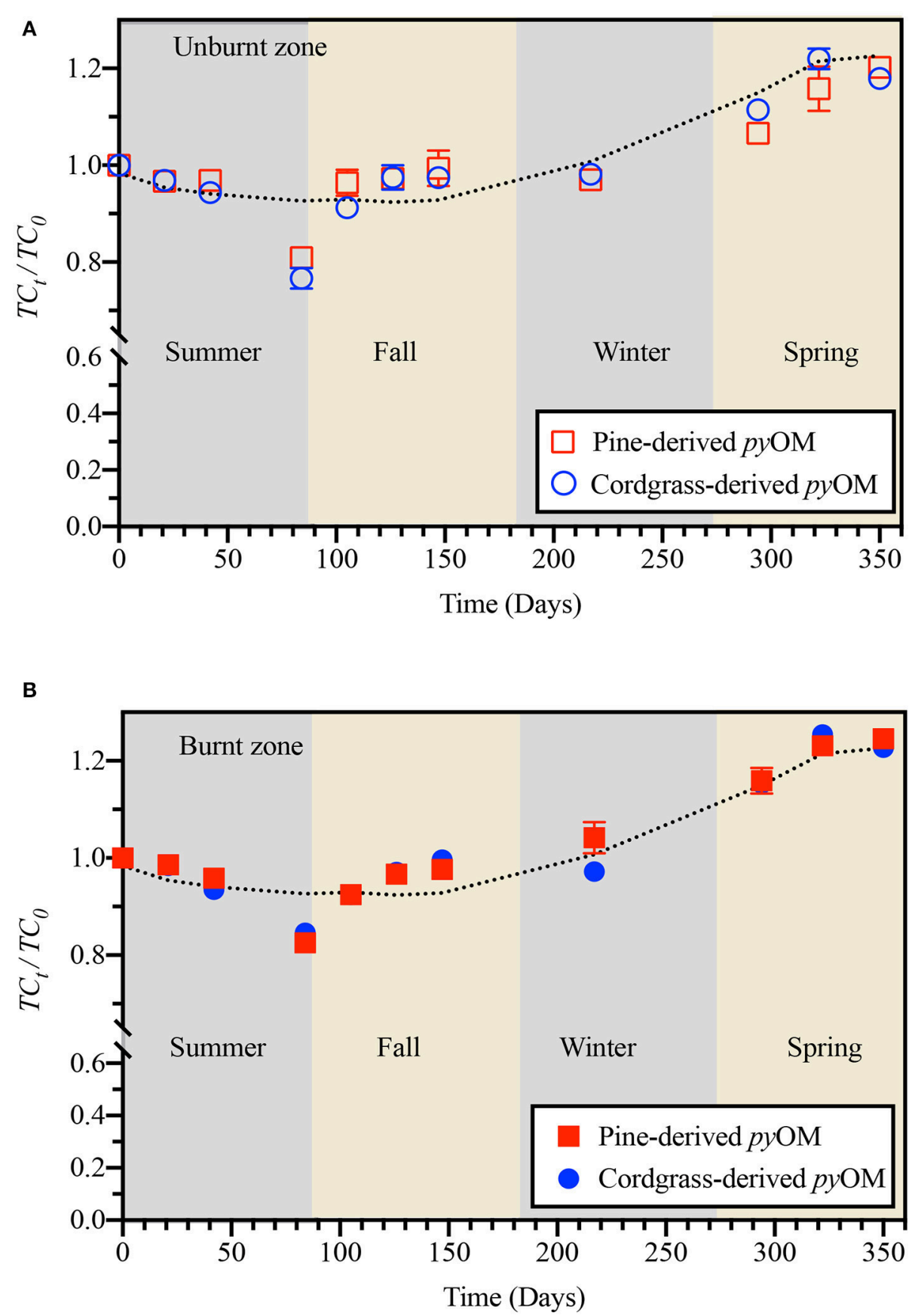

FIGURE 2 | Temporal variation in relative pyOM-associated carbon for pine- and cordgrass-derived pyrogenic organic matter buried to a soil depth of $8 \mathrm{~cm}$ in either the (A) unburnt or (B) burnt fire management zone. Values are based on ash-free carbon content of pyOM at sampling, relative to that of the initial material. Lines indicate model trace from generalized linear modeling.

0.476 , respectively. The relative recalcitrance, $R_{50}$, of pinederived pyOM generally decreased with increasing soil residence time. The $R_{50}$ of pine-derived pyOM in burned and unburned areas stabilized after $\sim 200$ days $\left(R_{50}=0.512\right.$ and 0.518, respectively). Irrespective of fire history, the $R_{50}$ values of the cordgrass-derived $p y \mathrm{OM}$ increased in a logarithmic pattern with time but also converged around 0.508 and 0.518 - similar to the pine-derived $p y \mathrm{OM}$. Not only were the trajectories in $R_{50}$ values of pine- and cordgrass-derived $p y \mathrm{OM}$ different, but the rates of change varied as well. For pine-derived $p y \mathrm{OM}$ the sigmoidal decrease in $R_{50}$ occurred around late summer-early fall and reaching a minimum in winter. For cordgrass-derived $p y \mathrm{OM}$, the increasing segment of the $R_{50}$-time relationship reached a maximum $R_{50}$ around late fall-early winter. 

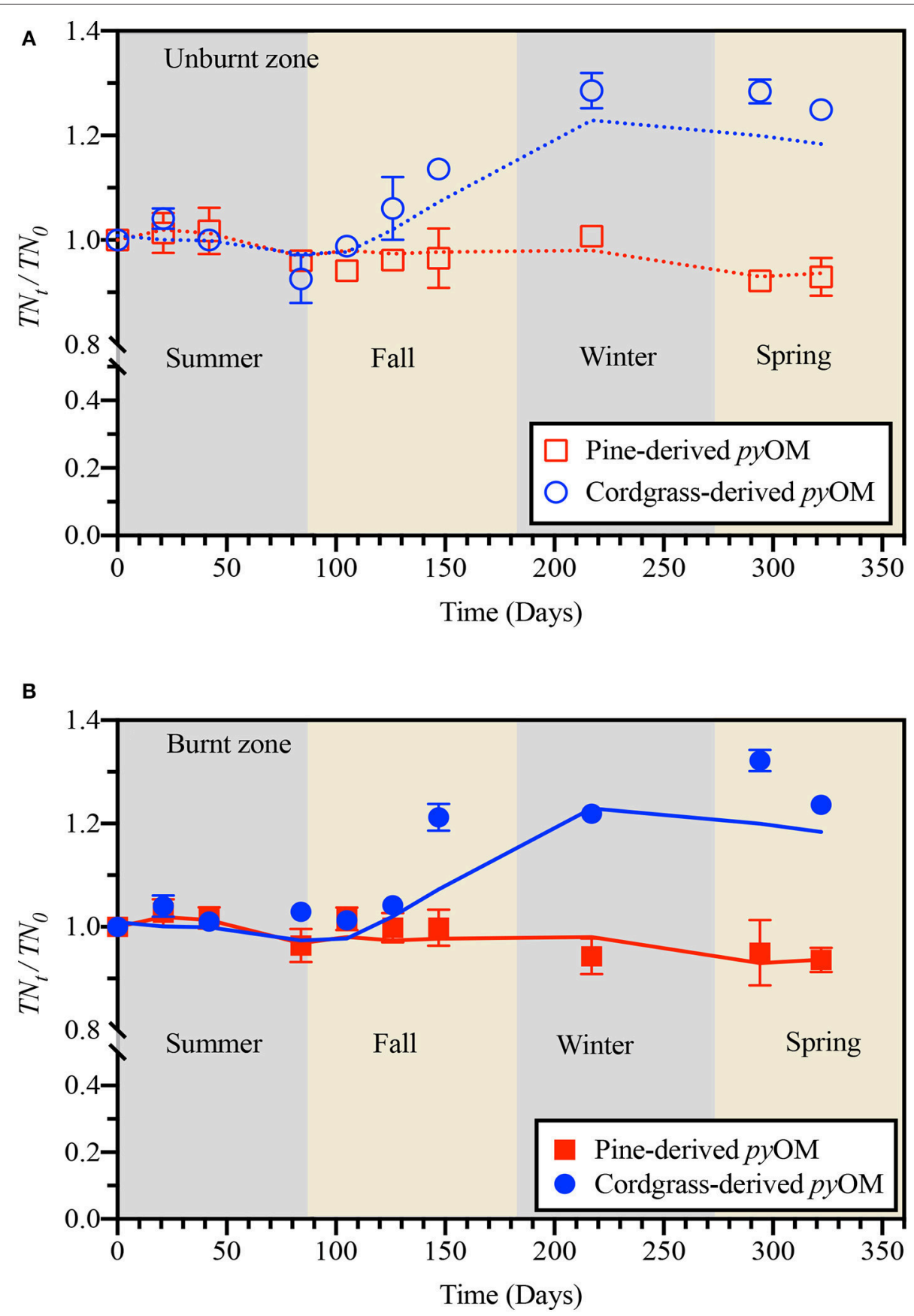

FIGURE 3 | Temporal variation in relative pyOM-associated nitrogen for pine- and cordgrass-derived pyrogenic organic matter buried to a soil depth of $8 \mathrm{~cm}$ in either the (A) unburnt or (B) burnt fire management zone. Values are based on ash-free nitrogen content of pyOM at sampling, relative to that of the initial material. Lines indicate model trace from generalized linear modeling.

Generalized linear modeling of changes in $R_{50}$ was possible for cordgrass-derived but could not be successfully applied to pinederived $p y \mathrm{OM}$. In the case of cordgrass-derived $p y \mathrm{OM}$, variability in $R_{50}$ in both the burnt and unburnt zone was shown to be predominantly driven by interaction-only effects (between $\mathrm{FH}$ and $T_{\text {avg }}, S R T$ and $P_{\text {cum }}, S R T$ and $T_{a v g}, S R T$ and $T_{\text {avg }}$ ) and could be modeled as,
$R_{50}=-3.57 \times 10^{-4}\left(\mathrm{FH} \times \mathrm{T}_{\text {avg }}\right)-1.06 \times 10^{-7}\left(\mathrm{SRT} \times \mathrm{P}_{\text {cum }}\right)-$ $1.38 \times 10^{-5}\left(S R T \times T_{\text {avg }}\right)+7.16 \times 10^{-6}\left(P_{\text {cum }} \times T_{\text {avg }}\right)+0.480$, with the model accounting for $88-93 \%$ of variability in both cases (Supplementary Figure 6). However, such an assessment was not possible for pine-derived pyOM-because none of the tested co-factors in our main-effects only, interactions-only or mixed effects models were significant at the $p=0.05$ level. 

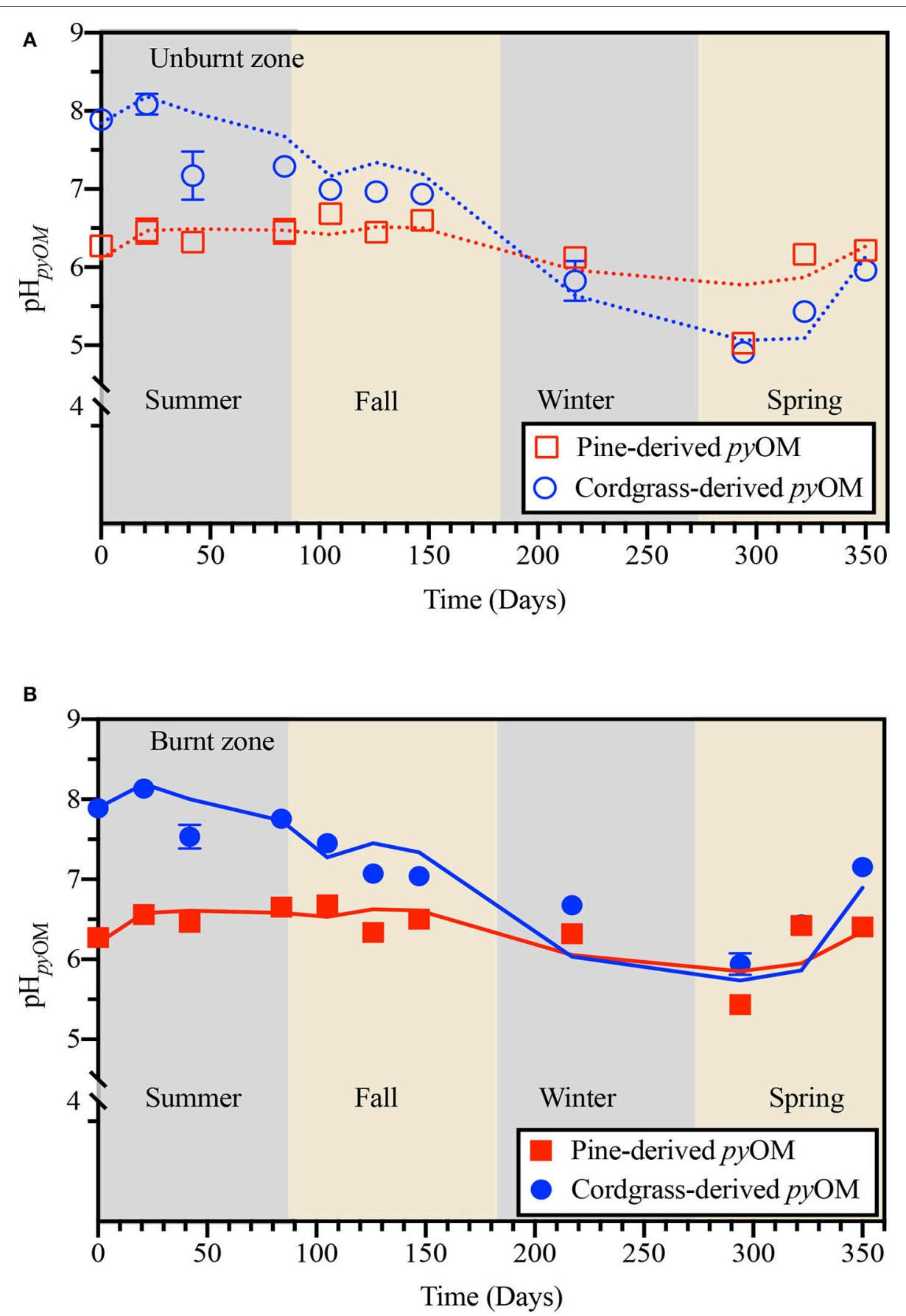

FIGURE 4 | Temporal variation in the $\mathrm{pH}$ of pine- and cordgrass-derived pyrogenic organic matter $(\mathrm{pH}$ pyOM) buried to a soil depth of $8 \mathrm{~cm}$ in either the (A) unburnt or (B) burnt fire management zone. Values are based on a 1:100 pyOM: water ratio. Lines indicate model trace from generalized linear modeling.

\section{Impact on Soil Properties}

Soils immediately below the buried pine- and cordgrass-derived pyOM did not show significant difference in $\mathrm{pH}$ across feedstock but were more acidic in the unburnt $(\mathrm{pH}=5.74 \pm 0.05)$ than burnt zone ( $\mathrm{pH}=6.00 \pm 0.04$; Supplementary Figure 7). By the first sampling excursion, the $\mathrm{pH}$ of the soil immediately beneath the litterbag in the unburnt zone increased to $5.92 \pm 0.03$ (in both pine- and cordgrass-derived $p y \mathrm{OM}$ ) and in the burnt zone to $6.12 \pm 0.03$ (cordgrass-derived $p y \mathrm{OM}$ ). This increase in $\mathrm{pH}$ was accompanied by a decrease in the electrical conductivity of the pyOM from $523 \pm 2.29$ to $21.7 \pm 1.38$ and $23.2 \pm$ $3.40 \mu \mathrm{Sm}^{-1}$ in the burnt and unburnt zone, respectivelywith $66-79 \%$ of this decrease occurring within the first 21 days (Supplementary Figure 8). The concomitant decline in soil $\mathrm{pH}$ 
and $p y \mathrm{OM}$ electrical conductivity continued over the fall and winter excursions. In the spring sample excursions, the $\mathrm{pH}$ of the soil immediately below the litterbags increased to it initial values.

As with soil $\mathrm{pH}$, SOC content immediately beneath the buried pyOM litterbags were similar under pine- and cordgrass-derived pyOM; averaging $2.08 \pm 0.07 \mathrm{wt} \%$ in the burnt zone and 1.47 $\pm 0.07 \mathrm{wt} \%$ in the unburnt zone (Supplementary Figure 9). In samples from excursions during the latter part of the fall into winter, there was evidence of a comparatively lower SOC content, compared to samples from other excursions.

\section{DISCUSSION}

\section{Dynamics of pyOM-Associated Carbon and Nitrogen}

Early stage decreases in pyOM-associated carbon and nitrogen, such as that observed during the summer season of the study, has been attributed to loss of labile components of pyOM via microbially-mediated degradation, volatilization and/or precipitation-induced leaching (Rajkovich et al., 2012; Norwood et al., 2013; Mukherjee et al., 2014; Sorrenti et al., 2016). At first glance, the microbially-mediated degradation of labile components in pyOM during summer seemed plausible and was supported to some extent by the fact that most of the loss in carbon and nitrogen (between sampling days 42 and 84) coincided with a $4-5^{\circ} \mathrm{C}$ increase in air temperature from 31 to $36^{\circ} \mathrm{C}$ (Supplementary Figure 10 ). These temperatures, as well as their observed increase during periods of highest carbon and nitrogen loss, were well within the range for optimal soil microbial activity and (all else being constant) would be expected to trigger increased microbial activity (Andersson and Nilsson, 2001; Liang et al., 2003).

Volatilization and/or precipitation-induced leaching/flushing of water-soluble organic components for the observed decrease in pyOM-associated carbon and nitrogen were also plausible. With the observed increase in $T_{\text {avg }}$ over the summer, the volatilization of volatile organic compounds (VOCs) formed during pyOM formation can be expected; and has been previously linked to the loss of $\mathrm{CO}_{2}-\mathrm{C}$ from $p y \mathrm{OM}$ with subsequent oxidation of the pyOM surface (Bruun et al., 2008; Steiner et al., 2008; Rajkovich et al., 2012). Potential support for precipitationinduced leaching/flushing was provided by the occurrence of several rainfall events (ranging in size from 2.54 to $43 \mathrm{~mm}$ ) during this period (Supplementary Figure 10). As noted earlier, these events were accompanied by sharp declines in the electrical conductivity of the buried pyOM, indicative of the flushing of salts from the materials (Supplementary Figure 8). It is therefore plausible that rain-induced flushing of salts from $p y O M$ would also trigger the concomitant leaching of water-soluble carbon and nitrogen from the $p y \mathrm{OM}$ as well.

Direct evidence from $\delta^{13} \mathrm{C}$ isotopic signatures of the residual pyOM was more supportive of precipitation-induced leaching of water-soluble organic components (than the microbial-mediated degradation) as significant driver for observed organic carbon loss in this study. The average $\delta^{13} \mathrm{C}$ in pine- and cordgrassderived $p y \mathrm{OM}$ on day 21 was $-28.4 \pm 0.05$ and $-23.9 \pm 0.22 \%$ respectively and did not change significantly in the unburnt or burnt zones between days 21 and 84-when pyOM-associated carbon loss was observed (Figure 6). This lack of evidence for a significant shift in the $\delta^{13} \mathrm{C}$ signature of $p y \mathrm{OM}$-associated carbon was inconsistent with expectations for the microbialmediated oxidation in aerobic surface soils such as those in the study. In such soils, microbial degradation is accompanied by ${ }^{12} \mathrm{C}$ enrichment of released $\mathrm{CO}_{2}$ and ${ }^{13} \mathrm{C}$ enrichment of the residual OM (Ågren et al., 1996; Feng, 2002; Wang et al., 2015). Conversely, the leaching of water-soluble organic components from $p y \mathrm{OM}$ without significant microbial transformation can be expected to have little or no effect on $\delta^{13} \mathrm{C}$ signature (Cleveland et al., 2004). The role of carbon mineralization via the volatilization of VOCs could not be ruled out as significant contributor to the observed loss of pyOM-associated carbon. In fact, given (1) the lack of isotopic support for microbial mineralization and (2) that $P_{c u m}, S R T$ and $T_{a v g}$ (i.e., the GLM model in Figure 2) accounted for only 6 of $15-25 \%$ of pyOMassociated carbon lost in the first 84 days ( $\sim 3$ months), it was quite justifiable that of the three potential processes; volatilization was the process that would account for the greatest loss of pyOM-associated carbon observed in this study.

The scenario would be somewhat different for losses of $p y \mathrm{OM}-$ associated nitrogen. As the model fit in Figure 3 indicatesunlike for $p y \mathrm{OM}$-associated carbon - losses in $p y \mathrm{OM}$-associated nitrogen during summer could be fully accounted for by leaching (i.e., variations in $P_{\text {cum }}, S R T$, and $T_{\text {avg }}$ ). The fact that losses in pyOM-associated nitrogen were accompanied by an approximate $0.5 \%$ enrichment in the ${ }^{15} \mathrm{~N}$ signature of the residual $p y \mathrm{OM}$ (Figure 7) suggested that the water-soluble nitrogen lost from pyOM during leaching would be more depleted in ${ }^{15} \mathrm{~N}$ than the residual pyOM fraction remaining. ${ }^{15} \mathrm{~N}$-enrichment in soils has also been attributed to adsorption of microbially processed organic matter and/or increased abundance of soil fungi (Natelhoffer and Fry, 1988; Etcheverría et al., 2009; Wallander et al., 2009). However, neither of these mechanisms was well-supported by our data. Firstly, the net loss of nitrogen, observed during summer, would rule out adsorption as important contributor to ${ }^{15} \mathrm{~N}$ enrichment. Secondly, there was no evidence for significant fungal colonization of $p y \mathrm{OM}$ during the early stages of experiment associated with summer losses of $p y \mathrm{OM}$ associated nitrogen. In fact, temporal trends in ergosterol content of $p y \mathrm{OM}$ pointed to summer as being the least biotically-active period-from a fungal perspective-in the study (Supplementary Figure 6). For instance, it is well-known that fungi are the primary degraders of $p y \mathrm{OM}$ in forest soils (Steinbeiss et al., 2009), and as such the ergosterol in fungal cells is widely used as a biomarker for fungal activity (Djajakirana et al., 1996; Mille-Lindblom et al., 2004). However, the fact that measured ergosterol content of pyOM was significantly lower in summer $\left(2-5 \mu \mathrm{g} \mathrm{g}^{-1}\right.$ of $\left.p y \mathrm{OM}\right)$ than in spring (13 $\mu \mathrm{g} \mathrm{g}^{-1}$ of $p y \mathrm{OM}$ ) was consistent with the lowest fungal/biotic activity coinciding with greatest and only occurrence of losses in pyOM-associated carbon (Supplementary Figure 11).

The re-accumulation of $p y \mathrm{OM}$-associated carbon and nitrogen we observed throughout fall and into spring was consistent with both the trajectory and magnitudes reported by 

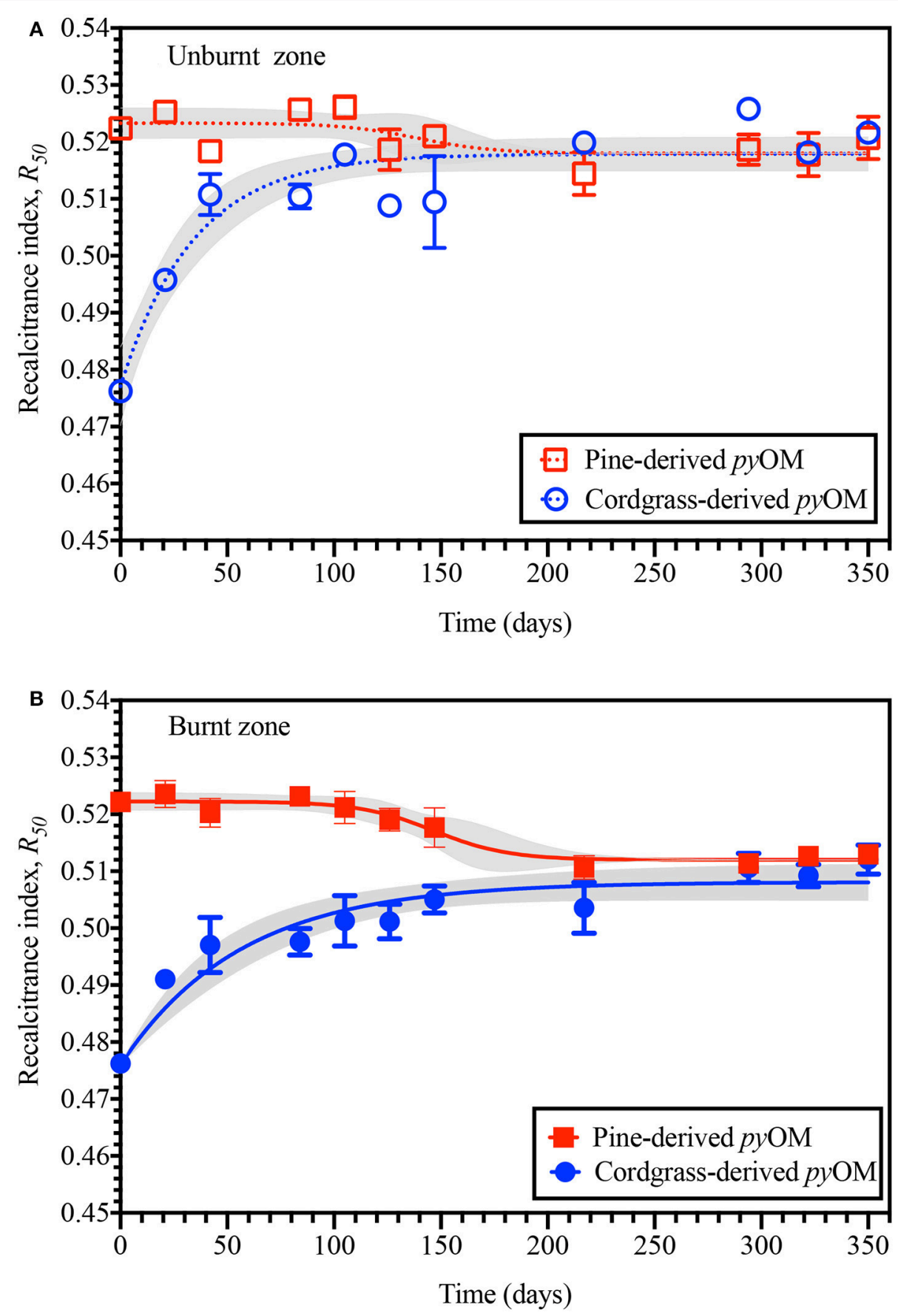

FIGURE 5 | Temporal variation in the relative recalcitrance $\left(R_{50}\right)$ of pine- and cordgrass-derived pyrogenic organic matter buried to a soil depth of $8 \mathrm{~cm}$ in either the (A) unburnt or (B) burnt fire management zone. Values are based on the thermal oxidation of the respective pyOM to that of graphite.

Mukherjee et al. (2014). In their study, Mukherjee et al. (2014) found that the burial of oak, pine and grass $p y \mathrm{OM}$ (produced at $\geq 400^{\circ} \mathrm{C}$ ) for a soil residence time of 15 months (May 1, 2009 to September 1,2010 ) resulted in an increase of up to 124 and $143 \%$ in associated carbon and nitrogen, respectively. They attributed the observed increases to variations in the two soils and $p y \mathrm{OM}$ type studied. Interestingly, the experiments of Mukherjee et al.
(2014) were also conducted within the Long leaf pine region about 490 miles east of our site, under comparable average temperatures and cumulative rainfall but in very different soils. That our study conditions differed from Mukherjee et al. (2014) primarily in soil types but yielded similar overall trends in pyOM dynamics brings into question the overall importance of soil type in $p y \mathrm{OM}$ carbon and nitrogen dynamics in the 


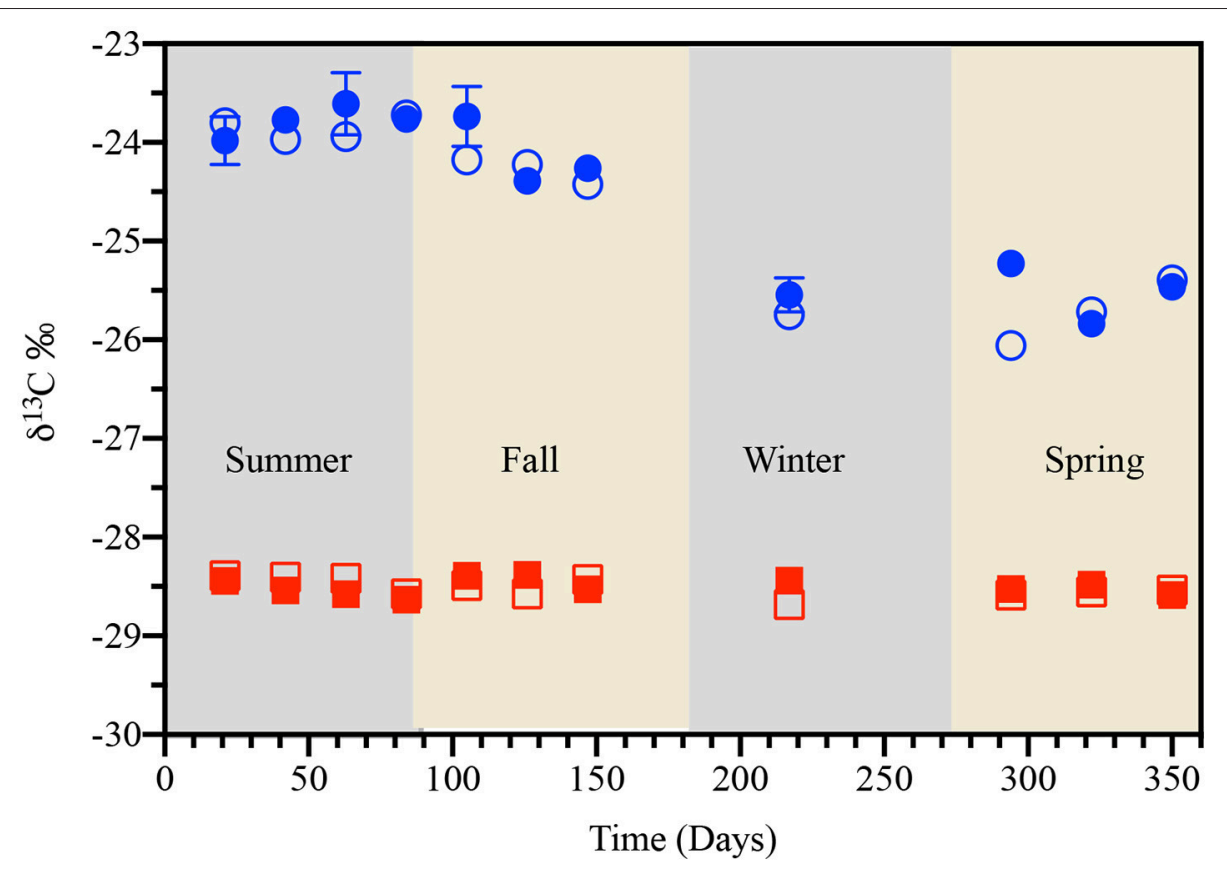

FIGURE 6 | Temporal variation in the carbon isotope signature $\left(\delta^{13} \mathrm{C}\right)$ of pine- (red squares) and cordgrass-derived (blue circles) pyrogenic organic matter buried to a soil depth of $8 \mathrm{~cm}$ in either the unburnt (open symbols) or burnt (filled symbols) fire management zone. Values of $\delta^{13} \mathrm{C}$ are for sampling locations $\mathrm{U} 1$ (unburnt values), averages of B1 and B3 (burnt values), and are reported relative to the Vienna PeeDee Belemnite standard.

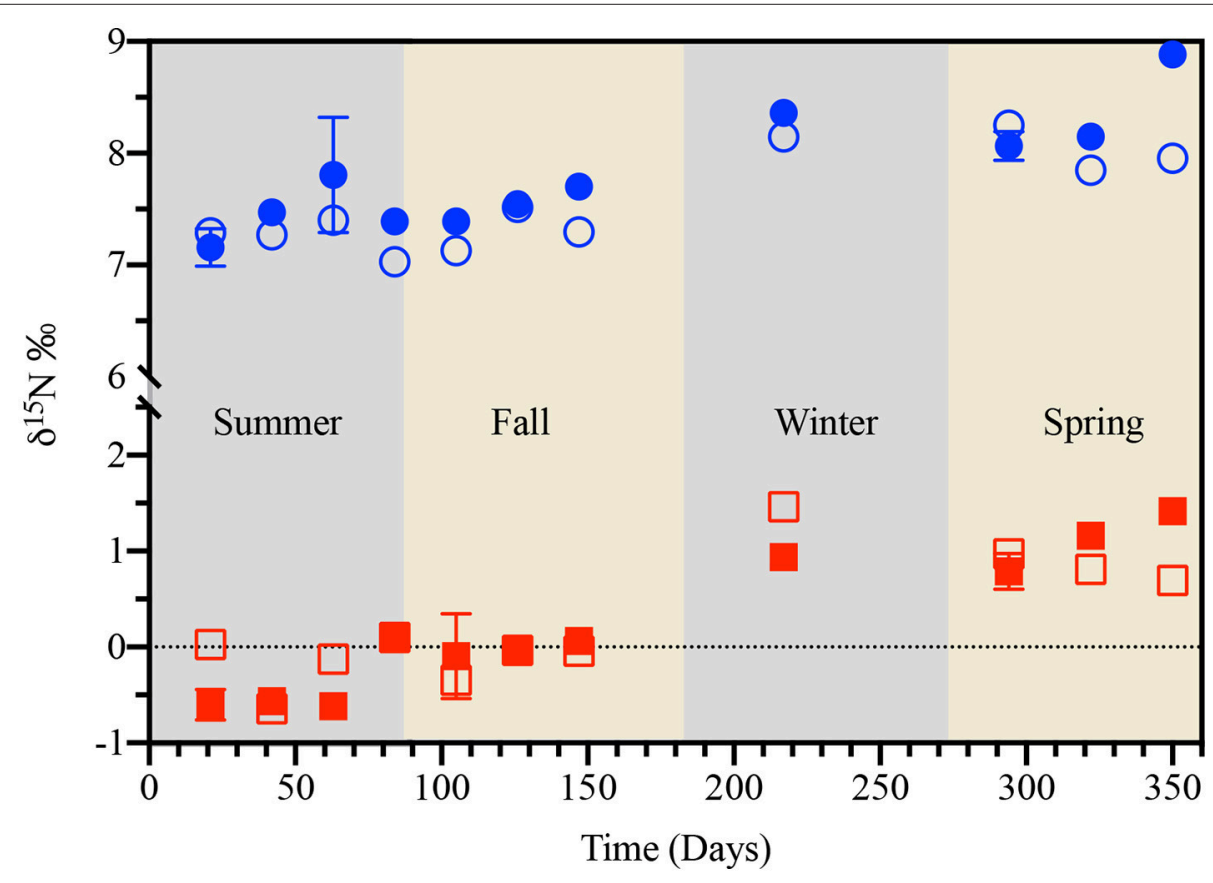

FIGURE 7 | Temporal variation in the nitrogen isotope signature $\left(\delta^{15} \mathrm{~N}\right)$ of pine- (red squares) and cordgrass-derived (blue circles) pyrogenic organic matter buried to a soil depth of $8 \mathrm{~cm}$ in either the unburnt (open symbols) or burnt (filled symbols) fire management zone. Values of $\delta^{15} \mathrm{~N}$ are for sampling locations $\mathrm{U} 1$ (unburnt values), averages of B1 and B3 (burnt values), and are reported relative to the international atmospheric $\mathrm{N}_{2}$ standard.

forested ecosystems of this area and most likely the region. Particularly, since like the spodosol and entisol of Mukherjee et al. (2014) and the ultisol at our site, the surface soils of the region are predominantly coarse (sandy) textured, with low $\mathrm{pH}$, low organic matter and low retention capacities (Shaw et al., 2004; Novak et al., 2009). Other studies have also reported either 
the accumulation of carbon (Kasin and Ohlson, 2013; Dong et al., 2017) or nitrogen (Sorrenti et al., 2016; de la Rosa et al., 2018), but not both, after the field aging of $p y \mathrm{OM}$ for up to 5 years. It is also interesting to note that for studies having similar trajectories in $p y \mathrm{OM}$ carbon and nitrogen dynamics, there were suggestions of similar climate-either similar Koppen-Geiger climate classification (continental climate; Kasin and Ohlson, 2013; Dong et al., 2017) or similar annual precipitations and temperatures (Sorrenti et al., 2016; de la Rosa et al., 2018). In all these cases, carbon or nitrogen accumulations in $p y \mathrm{OM}$ were attributed to the sorption of exogenous components (inorganic or organic) and/or microbial/fungal colonization.

Our data showing accumulations of $p y \mathrm{OM}$-associated carbon and nitrogen, from fall through spring, was consistent with this latter explanation of exogenous carbon and nitrogen sorption to and/or the microbial colonization of the $p y \mathrm{OM}$. Specifically, the climate-driven leaching of microbially "reworked" exogenous water-soluble organic matter and its subsequent sorption to the $p y \mathrm{OM}$. Firstly, the fact that both carbon and nitrogen accumulations could be effectively modeled by considering only variations in $P_{\text {cum }}, T_{\text {avg }}$, and $S R T$ points to the critical role of climatic conditions (Figures 2, 3). Secondly, the exceedance of the initial carbon and nitrogen values as shown in Figures 2, 3 for this period coupled with an accompanying ${ }^{13} \mathrm{C}$ depletion in carbon (from $\delta^{13} \mathrm{C}=-23.9$ to $-25.7 \%$ o; Figure 6) associated with cordgrass-derived $p y \mathrm{OM}$ was reflective of an exogenous source that is isotopically lighter than cordgrass. Thirdly, the presence of ${ }^{15} \mathrm{~N}$ enrichment in cordgrass $p y \mathrm{OM}$ was reflective of the associated exogenous $\mathrm{N}$ being isotopically heavier than the residual $p y \mathrm{OM}-$ consistent with microbial processing of this nitrogen prior to its interaction with $p y \mathrm{OM}$ (Figure 7). The fact that nitrogen accumulation was only apparent in cordgrass-derived $p y \mathrm{OM}$ suggested the preferential association of this exogenous nitrogen with functional groups that are more prevalent in the cordgrass- than the pine-derived pyOM.

Increasing quantities of base-extracted organic carbon (BEOC) associated with both pine- and cordgrass-derived pyOM, over the course of the study, further supported an exogenous origin for the re-accumulated pyOM-associated carbon (Supplementary Figure 12). The increasing trends in BEOC with $S R T$ also suggested that the plateau in carbon re-accumulation on $p y \mathrm{OM}$ around late fall or winter was more reflective of a lowered availability of "labile" carbon rather than saturation of the $p y \mathrm{OM}$ sorption capacity. A lowered availability of organic carbon in late fall and winter was attributable to lowered temperatures and rainfall favoring a decrease in microbial processing of organic matter, leaching and subsequently a decrease in water-soluble organic matter available for sorption. The lack of $\delta^{13} \mathrm{C}$ depletion (or enrichment) for the pine-derived pyOM $\left(\delta^{13} \mathrm{C}=-28.3 \%\right.$; Figure 6) pointed to leachate from pine needles, fungal biomass and other similarly ${ }^{13} \mathrm{C}$-depleted components of litter/soil organic matter as possible sources (McDowell and Likens, 1988; Qualls and Haines, 1991; Wallander et al., 2009) Increasing availability of this more ${ }^{13} \mathrm{C}$-depleted carbon-due to needle shedding, senescence and biotic degradation-would account for the re-accumulation of pyOM-associated carbon in early to mid-fall (Figure 2). Lower temperatures and rainfall, as well as lower biotic activity would explain the reduce availability and hence plateauing in carbon re-accumulation during the latter parts of fall into winter. The return of higher temperatures and rainfall would explain further increases in $p y \mathrm{OM}$-associated carbon content (from 1 to 1.25 times initial values) observed during spring. As temperature increases in spring, an increase in biotic activity, resulting in more water-soluble organic matter being available for association with $p y \mathrm{OM}$ via for sorption-as in fall. However, as opposed to fall when microbial processing of senescenced plant biomass would drive availability of exogenous carbon, in spring root exudates released to enhance nutrient uptake (as plant shift from dormancy to active growth) would be a potential source of exogenous carbon available for sorption (Mergel et al., 1998; Nardi et al., 2000; Richardson et al., 2011; Keiluweit et al., 2015).

It is worth noting that although increased $p y \mathrm{OM}$-associated ergosterol was observed with time in all but our pine-derived pyOM in the unburnt zone (Supplementary Figure 11) the role of fungal colonization in observed pyOM dynamics is not unequivocal. For instance, the range of ergosterol values were well within expectations for mineral soils without fungal colonization (Sung et al., 1995; Djajakirana et al., 1996; Frostegård and Bååth, 1996). Therefore, it is quite plausible that the observed increase ergosterol with SRT was exogenous and a result of its sorption to the $p y \mathrm{OM}$ rather than colonization by fungi. Such persistence is not unexpected given the likely protection of fungal biomass by forest litter from sunlight (MilleLindblom et al., 2004).

\section{Dynamics of pyOM pH and Stability}

The differences observed in initial $\mathrm{pH}$ in the study was attributable to differences in source material (i.e., pine- vs. cordgrass-derived $p y \mathrm{OM}$; de la Rosa et al., 2018). The generally lower $\mathrm{pH}$ values and lower $\mathrm{pH}$-sensitivity of pine-derived $p y \mathrm{OM}$, compared to its cordgrass-derived counterpart, was reflective of the acidic conditions typical of the soils in pine forest ecosystems. Cordgrass, on the other hand, is native to coastal regions where $\mathrm{pH}$ is usually more basic and more reflective of seawater $\mathrm{pH}$ (around $\mathrm{pH}$ 8-8.2). The $\mathrm{pH}$ of a basic material in an acidic environment is expected to decline as it adjusts to equilibrium conditions, thus the observed decline in $\mathrm{pH}$ in cordgrass-derived $p y \mathrm{OM}$. Declines in $p y \mathrm{OM} \mathrm{pH}$ with aging/SRT has been widely observed and is attributable to the weathering-induced oxidation of basic to acidic functionalities (e.g., alcohols to carboxyls), the dissolution of carbonates or (oxy)hydroxides and/or the leaching and exchange of basic cations with $\mathrm{H}^{+}$or acidic cations (Joseph et al., 2010; Yao et al., 2010; Spokas et al., 2012; Sorrenti et al., 2016; de la Rosa et al., 2018). All three of these mechanisms were quite plausible in our study given the observed flushing of salts and observations by others indicating increased ion exchange with aging of pyOM (Cheng et al., 2008; Mukherjee et al., 2014). The fact that the largest declines in $p y \mathrm{OM} \mathrm{pH}(1-2 \mathrm{pH}$ units; fall through early spring) coincided with period of accumulation for exogenous carbon and nitrogen further points to the acidic nature of the exogenous organic matter being leached from litter and partitioned to the $p y \mathrm{OM}$. 
The fact that the decline in $\mathrm{pH}$ at day 217 was seen in both types of $p y \mathrm{OM}$ and is associated with the transition from winter to spring, suggested that the change was likely linked to a seasonally-driven shift in environmental conditions. The most likely trigger is the occurrence of several large precipitation events throughout winter into early spring (between days 210 and 240; Supplementary Figure 10). This period represented the most intense period of precipitation, resulting in an influx of more acidic exogenous materials and the observed decline in $\mathrm{pH}$ of both pine- and cordgrass-derived $p y \mathrm{OM}$ between sampling day 217 and 294. This would also be consistent with results from GLM indicative of $P_{\text {cum }}, T_{\text {avg }}$, and $S R T$ being significant parameters in explaining observed variations in the $\mathrm{pH}$ of $p y \mathrm{OM}$. The rebound of $p y O M \mathrm{pH}$ back to more circumneutral conditions ( $\mathrm{pH}$ 6.0-7.2) by the end of the study was congruent with eventual loss of acidic exogenous materials via their neutralization through the ingress of basic cations mobilized by root exudates into the $p y \mathrm{OM}$. The difference in the absolute magnitudes of $\mathrm{pH}$ declines and subsequent rebound observed across fire history can be reasonably explained as a fire-induced soil buffering effect; where previous burning imparts a higher soil buffering capacity to soils in the burnt zone (Mukherjee et al., 2014; Wang et al., 2014; Shi et al., 2017, 2018). The source of this buffering would be increased cation exchange capacity and basic cation content arising from higher soil carbon and ash-contained basic cations contents accumulating over progressive burns. Therefore, these soils are better able to resist decreases in $\mathrm{pH}$ arising from ingress of exogenous organic matter and/or $\mathrm{H}^{+}$. This fire-induced buffering effect would also explain the significance of $\mathrm{FH}$ (specifically its interaction with $T_{\text {avg }}$ ), as identified via GLM, as an important parameter in explaining observed variability in $\mathrm{pH}$. We posit that as $T_{\text {avg }}$ decreases and plants shift into dormancy, the interaction of precipitation with senesced/senescing plant matter results in the leaching of exogenous organic matter (and $\mathrm{H}^{+}$) that flushes basic cations and gets sorbed to $p y \mathrm{OM}$ reducing its $\mathrm{pH}$. A rebounding of $T_{\text {avg }}$ in spring, the return of active plant growth and the associated release of root exudates triggered the release of basic cations from minerals with the leaching and ingress of these basic cations into $p y \mathrm{OM}$ triggering its increase in $\mathrm{pH}$ observed in the latter part of the study.

Measured $R_{50}$ values provided a proxy for the bulk recalcitrance (relative to graphite) of the $p y \mathrm{OM}$ remaining in the soil (Harvey et al., 2012). Since the exogenous carbon and nitrogen interacting with the $p y \mathrm{OM}$ was soil dissolved organic matter leached from the same source; the observed changes in $R_{50}$ were reflective of changes in the innate recalcitrance of the original $p y \mathrm{OM}$ material and/or the induced effects of the exogenous OM. Of such, observed $R_{50}$ provided insights into the overall recalcitrance or so called "quality" of the remaining pyOM.

The different temporal trajectories in $R_{50}$ observed in pinevs. cordgrass-derived $p y \mathrm{OM}$ can be reasonably explained by considering differences in feedstock structure and effect of associated water-soluble and exogenous OM. The interactions of these factors and subsequent impacts on recalcitrance $\left(R_{50}\right)$ are summarized in Figure 8. Initial differences observed in $R_{50}$ were attributable to structural differences between the pine- and cordgrass-derived pyOM (mainly the higher fraction of lignin in wood vs. grass feedstocks) that has been wellrecognized in a number of previous studies (e.g., McBeath and Smernik, 2009; Harvey et al., 2012). Over the summer, the lack of a significant change in $R_{50}$ values for pinederived $p y \mathrm{OM}$ indicated that the associated flushing of watersoluble OM (and salts) from this $p y \mathrm{OM}$ had no significant effect on its relative recalcitrance. This was consistent with the leached water-soluble components of pine-derived $p y \mathrm{OM}$ having comparable recalcitrance as the remaining residual pyOM component. By comparison, the increase in $R_{50}$ values for the cordgrass-derived $p y \mathrm{OM}$-over the same period-was consistent with the flushed water-soluble OM components of this pyOM being of lower recalcitrance than the remaining residual pyOM.

The decline in $R_{50}$ of pine-derived $p y \mathrm{OM}$ with the onset and subsequent increase in the accumulation of exogenous OM (in the $p y \mathrm{OM}$ ), over fall and winter, was reflective of this exogenous $\mathrm{OM}$ being of lower recalcitrance than the residual pyOM component. Therefore as the amount of exogenous OM associated with the pine-derived $p y \mathrm{OM}$ increased, its negative effect on $R_{50}$ was enhanced until an apparent plateauing point was reached in the latter part of winter. In contrast, the corresponding increase in $R_{50}$ for cordgrass-derived $p y \mathrm{OM}$ observed over fall and winter was congruent with exogenous $\mathrm{OM}$ having a positive effect (i.e., $R_{50}$ of exogenous $\mathrm{OM}$ is greater than that for residual $p y \mathrm{OM}$ ) on the overall recalcitrance of the cordgrass-derived pyOM; with this positive effect on recalcitrance also reaching a plateauing point in late winter.

Similarities in the timing and $R_{50}$ values at which plateauing occurred in cordgrass- and pine-derived $p y \mathrm{OM}$, within a given fire history, pointed to a common "equilibrium" $R_{50}$ $\left(R_{50, \text { eq }}\right)$. In addition to being reflective of the overall effect of residual $p y \mathrm{OM}$ and exogenous $\mathrm{OM}$ on $p y \mathrm{OM}$ recalcitrance, this $R_{50, \text { eq }}$ provide some interesting insights into overall pyOM recalcitrance as it pertains to, 1) fire history at the study site and 2) potential priming effects of exogenous $\mathrm{OM}$ on pyOM recalcitrance. Lower values for $R_{50, \text { eq }}$ in the burnt vs. unburnt zone suggested that $p y \mathrm{OM}$ was likely to have a comparatively lower persistence in soils with longer fire histories (Figure 8). Lower persistence of $p y \mathrm{OM}$ in soils with a history of fires have been attributed to the presence of microbial populations that are well-adapted to utilizing fire-derived carbon (Khodadad et al., 2011; Masiello et al., 2013). However, our results suggested that leaching and the modifying effects of exogenous OM are also important factors in $p y \mathrm{OM}$ persistence. For instance, in the case of cordgrass-derived $p y \mathrm{OM}$ the difference in $R_{50, e q}$ between the burnt and unburnt zones was established during the $p y \mathrm{OM}$ flushing stage-indicative of leaching differences. By comparison, in pine-derived $p y \mathrm{OM}$, the precedence for the observed difference in $R_{50, \text { eq }}$ between the burnt and unburnt zones was established during the stage of accumulation of exogenous $\mathrm{OM}-$ indicative of differences in the interaction between $p y \mathrm{OM}$ and exogenous $\mathrm{OM}$ in the fire zones being an important factor. 


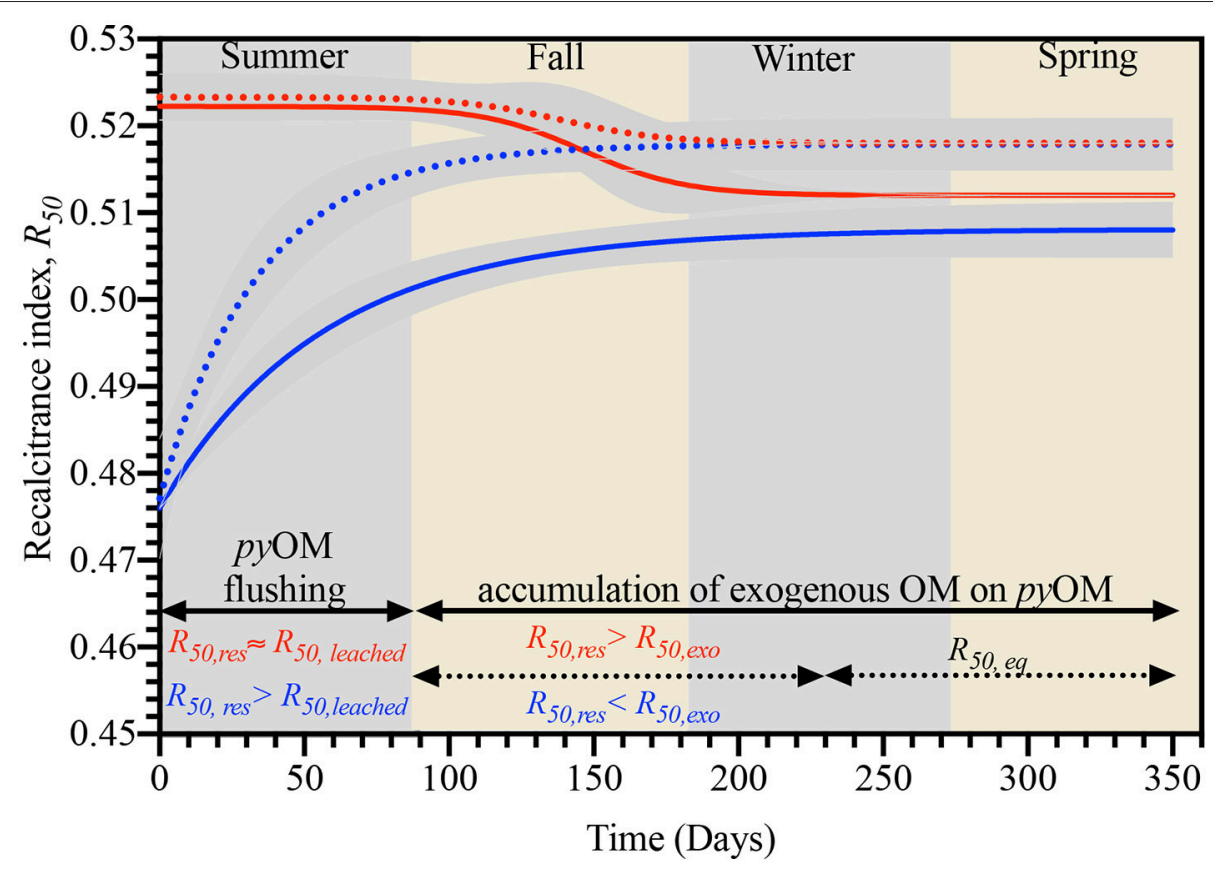

FIGURE 8 | Relationship between recalcitrance $\left(R_{50}\right)$ and processes (pyOM flushing and accumulation of exogenous OM) controlling biogeochemical dynamics of, pine- (red lines) and cordgrass-derived (blue lines) pyOM buried in either the unburnt (broken lines) or burnt (solid lines) fire management zone.

In terms of potential priming effects, the higher residual $R_{50}\left(R_{50, \text { res }}\right)$ at the end of summer for pine-derived materials compared to the corresponding $R_{50 \text {, eq }}$ (i.e., $R_{50 \text {, res }}>R_{50, e q}$ ) is consistent with exogenous OM reducing the overall recalcitrance of pyOM and hence favor positive priming (Figure 8). In contrast, the reverse situation $\left(R_{50, \text { res }}<R_{50 \text {, eq }}\right)$ existed for the cordgrass-derived pyOM, indicative of exogenous $\mathrm{OM}$ in the study area increasing overall recalcitrance of $p y \mathrm{OM}$ and hence is most likely to result in negative priming of $p y \mathrm{OM}$. The higher absolute magnitude of $R_{50}$, res minus $R_{50 \text {, eq }}$ in burnt vs. unburnt fire zones suggest that the priming effects of exogenous $\mathrm{OM}$ on pyOM degradability would be more pronounced in soils with an history of fire/pyOM input.

\section{Temporal Changes in Soil Within the Vicinity of the pyOM}

The overall acidic $\mathrm{pH}$ conditions of the soils were consistent with expectations, for soils within a pine forest ecosystem (Falkengren-Grerup, 1987) while the higher $\mathrm{pH}$ conditions observed in burnt vs. unburnt soils were consistent with the presence of basic salts (e.g., $\mathrm{CaO}$ and $\mathrm{CaCO}_{3}$ )-produced as components in the ash byproduct of plant biomass pyrolysis (Bodí et al., 2014; Wang et al., 2014 and references therein). The concomitant increase in the $\mathrm{pH}$ of the soil immediately beneath the litter bags, with loss in $p y \mathrm{OM}$ electrical conductivity, after the first excursion was consistent with in-situ flushing of basic salts from ash (13-14 wt\%) within the pyOM into the immediate soil. The role of ash components in early soil $\mathrm{pH}$ modification was well-supported by evidence from temporal changes in the electrical conductivity of CG-derived pyOM consistent with enhanced in-situ flushing of the pyOM within the first 21 days of the study (Supplementary Figure 8). For example, over the course of the study the electrical conductivity of the CG-derived pyOM decreased from $523 \pm 2.29 \mu \mathrm{S}$ $\mathrm{cm}^{-1}$ to $21.7 \pm 1.38$ and $23.2 \pm 3.40 \mu \mathrm{S} \mathrm{cm} \mathrm{cm}^{-1}$ in the burnt and unburnt zone, respectively. However, 66-79\% of this decrease in electrical conductivity occurred within the first 21 days-congruent with the vast majority of basic salts being leached from the pyOM during this period into the soil below.

The continued decline in soil $\mathrm{pH}$ and $p y \mathrm{OM}$ electrical conductivity observed for the fall and winter excursions reflected continued leaching and the loss of basic salts from the soils immediately below the litterbags. The subsequent increase in soil $\mathrm{pH}$ for the spring sample excursions suggested either a latter influx of basic salts into, or loss of acidic components from, the soil immediately below the pyOM. However, the lack of an accompanying decrease in $p y \mathrm{OM}$ electrical conductivity evidence would exclude ash from the $p y \mathrm{OM}$ as the source of the observed increase in soil $\mathrm{pH}$ in the spring. The actual source of this increase in soil $\mathrm{pH}$ is unclear at this time but is likely linked to temperature- and precipitation-enhanced process(es)in particular the root exudate enhanced mobilization of base cations from minerals as plants return to active growth from dormancy.

Higher SOC content in the burnt zone was consistent with the migration and storage of $p y \mathrm{OM}$ from previous burning events below the soil surface (Supplementary Figure 9). The lower SOC content in samples from late fall and winter, compared to the other seasons, was congruent with decreasing soil $\mathrm{pH}$ trends and 
suggest an association of leaching with lower SOC immediately below the buried litterbag (Supplementary Figure 4).

\section{SUMMARY AND CONCLUDING REMARKS}

In an effort to better understand the factors driving earlystage pyOM dynamics we studied the chemical evolution of freshly produced cordgrass- and pine-derived pyOM over the first year post-burial in pine-forest soils with similar origins (parent material and texture) but very different fire management histories. Results from the study indicated that spatially-driven factors had little to no effect on pyOM dynamics in the shortterm (up to 1 year). By comparison, temporally-variable factors such $S R T, P_{\text {cum }}, T_{\text {avg }}$ and to a lesser degree the land management factor, $F H$ were found to be the primary contributors to observed variation in the biogeochemical dynamics-specifically pyOM-associated carbon content, nitrogen content, $\mathrm{pH}$ and bulk recalcitrance-of $p y \mathrm{OM}$ from different sources. Interestingly, we found no evidence to support microbially-driven mineralization of $p y \mathrm{OM}$ as an important driver of $p y \mathrm{OM}$ dynamics in this study. Instead, the volatilization of VOCs and/or the leaching of water-soluble components from the $p y \mathrm{OM}$ were most plausibly controlling pyOM dynamics in the first 3 months (i.e., summer) of the study; while in the next 9 months (i.e., fall through spring), the dynamics of $p y \mathrm{OM}$ was likely controlled by availability of exogenous organic matter and its interaction with $p y \mathrm{OM}$.

The volatilization of VOCs and the flushing of water-soluble components from pyOM (including water-soluble organic matter) during the first 3 months resulted in (1) a decrease in pyOM-associated carbon, (2) minimal effect on $p y \mathrm{OM}$-associated nitrogen or the overall stability of pine-derived $p y \mathrm{OM}$ but (3) increased the overall stability of cordgrass-derived pyOM. The increasing availability of labile exogenous organic matter (from needle fall and senescence in fall and root exudates in spring) resulted in a re-accumulation/accumulation of $p y \mathrm{OM}$ associated carbon and nitrogen (for cordgrass-derived $p y \mathrm{OM}$ ) in fall through to spring. Interaction of this exogenous organic matter with $p y \mathrm{OM}$ caused an initial decrease and increase in the recalcitrance of pine-derived and cordgrass-derived pyOM, respectively - with an eventual convergence in recalcitrance for both pyOMs by mid-winter. A higher recalcitrance convergence

\section{REFERENCES}

Ågren, G. I., Bosatta, E., and Balesdent, J. (1996). Isotope discrimination during decomposition of organic matter: a theoretical analysis. Soil Sci. Soc. Am. J. 60, 1121-1126. doi: 10.2136/sssaj1996.036159950060000 $40023 \mathrm{x}$

Alexis, M. A., Rasse, D. P., Rumpel, C., Bardoux, G., Pechot, N., Schmalzer, P., et al. (2007). Fire impact on $\mathrm{C}$ and $\mathrm{N}$ losses and charcoal production in a scrub oak ecosystem. Biogeochemistry 82, 201-216.

Andersson, S., and Nilsson, S. I. (2001). Influence of ph and temperature on microbial activity, substrate availability of soil-solution bacteria and leaching of dissolved organic carbon in a mor humus. Soil Biol. Biochem. 33, 1181-1191. doi: 10.1016/S0038-0717(01)00022-0

Bird, M. I., Wynn, J. G., Saiz, G., Wurster, C. M., and McBeath, A. (2015). The pyrogenic carbon cycle. Annu. Rev. Earth Planet. Sci. 43, 273-298. doi: 10.1146/annurev-earth-060614-105038 point in the unburnt zone was congruent with a longer potential persistence of $p y \mathrm{OM}$ in these soils compared to that in the burnt zone. The decreasing effect of exogenous organic matter on pyOM recalcitrance suggests that native non-pyrogenic organic matter in the study area is likely to have a positive priming effect on any eventual microbial degradation.

The overall lack of evidence to support a significant microbiological influence-contrasted against that for volatilization, leaching of water-soluble pyOM, and sorption of exogenous organic matter-pointed overwhelmingly to physicochemical (rather than microbiological) processes as the primary drivers of early pyOM dynamics in our study system. Such results suggest that models of $p y \mathrm{OM}$ behavior (especially in the early stages) in humid subtropical systems may need to adopt a multifactorial approach in determining the factors dictating pyOM dynamics.

\section{AUTHOR CONTRIBUTIONS}

All authors were involved in the design of experiments and planning of analysis. JS and RA conducted field experiments; JS, $\mathrm{PL}$, and KK conducted laboratory analyses; $\mathrm{OH}$ and JS wrote the manuscript.

\section{ACKNOWLEDGMENTS}

Funding for this project was primarily through startup funds provided to $\mathrm{OH}$ by the University of Southern Mississippi and Texas Christian University. The authors are grateful to Drs. Michael Davis and Andy Reece for allowing access to the LTEC and weather station data, respectively. Dr. Ren Zhang at the Baylor University Stable Isotope Laboratory performed isotopic analysis on a fee basis. Stable isotope analysis was supported through an internal grant to OH from TCU's Andrew's Institute for Mathematics and Science Education.

\section{SUPPLEMENTARY MATERIAL}

The Supplementary Material for this article can be found online at: https://www.frontiersin.org/articles/10.3389/feart. 2018.00052/full\#supplementary-material

Bodí, M. B., Martin, D. A., Balfour, V. N., Santín, C., Doerr, S. H., Pereira, P., et al. (2014). Wildland fire ash: production, composition and Eco-Hydro-geomorphic effects. Earth Sci. Rev. 130, 103-127. doi: 10.1016/j.earscirev.2013.12.007

Bruun, S., Jensen, E. S., and Jensen, L. S. (2008). Microbial mineralization and assimilation of black carbon: dependency on degree of thermal alteration. Org. Geochem. 39, 839-845. doi: 10.1016/j.orggeochem.2008.04.020

Carvalhais, N., Forkel, M., Khomik, M., Bellarby, J., Jung, M., Migliavacca, M., et al. (2014). Global covariation of carbon turnover times with climate in terrestrial ecosystems. Nature 514, 213-217. doi: 10.1038/nature 13731

Cheng, C.-H., Lehmann, J., Thies, J. E., and Burton, S. D. (2008). Stability of black carbon in soils across a climatic gradient. J. Geophys. Res. 113:G02027. doi: 10.1029/2007JG000642

Cleveland, C. C., Neff, J. C., Townsend, A. R., and Hood, E. (2004). Composition, dynamics, and fate of leached dissolved organic matter in terrestrial 
ecosystems: results from a decomposition experiment. Ecosystems 7, 175-285. doi: 10.1007/s10021-003-0236-7

de la Rosa, J. M., Rosado, M., Paneque, M., Miller, A. Z., and Knicker, H. (2018). Effects Of aging under field conditions on biochar structure and composition: implications for biochar stability in soils. Sci. Tot. Environ. 613-614, 969-976. doi: 10.1016/j.scitotenv.2017.09.124

Djajakirana, G., Joergensen, R. G., and Meyer, B. (1996). Ergosterol and microbial biomass relationship in soil. Biol. Fertil. Soils 22, 299-304. doi: $10.1007 /$ BF00334573

Dong, X., Li, G., Lin, Q., and Zhao, X. (2017). Quantity and quality changes of biochar aged for 5 years in soil under field conditions. Catena 159, 136-143. doi: 10.1016/j.catena.2017.08.008

Etcheverría, P., Huygens, D., Godoy, R., Borie, F., and Boeckx, P. (2009). Arbuscular mycorrhizal fungi contribute to $13 \mathrm{c}$ and $15 \mathrm{n}$ enrichment of soil organic matter in forest soils. Soil Biol. Biochem. 41, 858-861. doi: 10.1016/j.soilbio.2009.01.018

Falkengren-Grerup, U. (1987). Long-term changes in ph of forest soils in southern sweden. Environ. Pollut. 43, 79-90. doi: 10.1016/0269-7491(87)90067-4

Feng, X. (2002). A theoretical analysis of carbon isotope evolution of decomposing plant litters and soil organic matter. Global Biogeochem. Cycles 16, 66-1. doi: 10.1029/2002GB001867

Flannigan, M. D., Stocks, B. J., and Wotton, B. M. (2000). Climate change and forest fires. Sci. Tot. Environ. 262, 221-229. doi: 10.1016/S0048-9697(00)00524-6

Frostegård, A., and Bååth, E. (1996). The use of phospholipid fatty acid analysis to estimate bacterial and fungal biomass in soil. Biol. Fertil. Soils 22, 59-65. doi: $10.1007 /$ BF00384433

Gee, G. W., and Bauder, J. W. (1986). "Particle-size analysis, in Methods of Soil Analysis; Part 1 Physical and Mineralogical Methods, 2nd Edn, ed A. Klute (Madison: American Society of Agronomy).

Hammes, K., Torn, M. S., Lapenas, A. G., and Schmidt, M. W. I. (2008). Centennial black carbon turnover observed in a russian steppe soil. Biogeosciences 5, 1339-1350. doi: 10.5194/bg-5-1339-2008

Harvey, O. R., Herbert, B. E., Harris, J. P., Stiffler, E. A., and Crenwelge, J.A. (2009). A new spectrophotometric method for rapid semiquantitative determination of soil organic carbon. Soil Sci. Soc. Am. J. 73, 822-830. doi: 10.2136/sssaj2008.0268

Harvey, O. R., Kuo, L. J., Zimmerman, A. R., Louchouarn, P., Amonette, J. E., and Herbert, B. E. (2012). An index-based approach to assessing recalcitrance and soil carbon sequestration potential of engineered black carbons (Biochars). Environ. Sci. Technol. 46, 1415-1421. doi: 10.1021/es2040398

Joseph, S. D., Camps-Arbestain, M., Lin, Y., Munroe, P., Chia, C. H., Hook, J., et al. (2010). An investigation into the reactions of biochar in soil. Soil Res. 48, 501-515. doi: 10.1071/SR10009

Kane, E. S., Hockaday, W. C., Turetsky, M. R., Masiello, C. A., Valentine, D. W., Finney, B. P., et al. (2010). Topographic controls on black carbon accumulation in alaskan black spruce forest soils: implications for organic matter dynamics. Biogeochemistry 100, 39-56. doi: 10.1007/s10533-0099403-z

Kasin, I., and Ohlson, M. (2013). An experimental study of charcoal degradation in a boreal forest. Soil Biol. Biochem. 65, 39-49. doi: 10.1016/j.soilbio.2013.05.005

Keiluweit, M., Bougoure, J. J., Nico, P. S., Pett-Ridge, J., Weber, P. K., and Kleber, M. (2015). Mineral protection of soil carbon counteracted by root exudates. Nat. Clim. Chang. 5, 588-595. doi: 10.1038/nclimate2580

Khodadad, C. L. M., Zimmerman, A. R., Green, S. J., Uthandi, S., and Foster, J. S. (2011). Taxa-specific changes in soil microbial community composition induced by pyrogenic carbon amendments. Soil Biol. Biochem. 43, 385-392. doi: 10.1016/j.soilbio.2010.11.005

Knicker, H. (2010). "Black Nitrogen" - an important fraction in determining the recalcitrance of charcoal. Organ. Geochem. 41, 947-950. doi: 10.1016/j.orggeochem.2010.04.007

Knicker, H., Hilscher, A., González-Vila, F. J., and Almendros, G. (2008). A new conceptual model for the structural properties of char produced during vegetation fires. Organ. Geochem. 39, 935-939. doi: 10.1016/j.orggeochem.2008.03.021

Kottek, M., Grieser, J., Beck, C., Rudolf, B., and Rubel, F. (2006). World map of the köppen-geiger climate classification updated. Meteorologische Zeitschrift 15, 259-263. doi: 10.1127/0941-2948/2006/0130
Kuehn, K. A., Ohsowski, B. M., Francoeur, S. N., and Neely, R. K. (2011). Contributions of fungi to carbon flow and nutrient cycling from standing dead typha angustifolia leaf litter in a temperate freshwater marsh. Limnol. Oceanogr. 56, 529-539. doi: 10.4319/lo.2011.56.2.0529

Lehmann, J., Gaunt, J., and Rondon, M. (2006). Bio-char sequestration in terrestrial ecosystems - a review. Mitigat. Adapt. Strateg. Global Change 11, 403-427. doi: 10.1007/s11027-005-9006-5

Lehmann, J., Skjemstad, J., Sohi, S., Carter, J., Barson, M., Falloon, P., et al. (2008). Australian climate-carbon cycle feedback reduced by soil black carbon. Nat. Geosci. 1, 832-835. doi: 10.1038/ngeo358

Liang, B., Lehmann, J., Solomon, D., Sohi, S., Thies, J. E., Skjemstad, J. O., et al. (2008). Stability of biomass-derived black carbon in soils. Geochim. Cosmochim. Acta 72, 6069-6078. doi: 10.1016/j.gca.2008.09.028

Liang, C., Das, K. C., and McClendon, R. W. (2003). The influence of temperature and moisture contents regimes on the aerobic microbial activity of a biosolids composting blend. Bioresour. Technol. 86, 131-137. doi: 10.1016/S0960-8524(02)00153-0

Markewitz, D., Sartori, F., and Craft, C. (2002). Soil change and carbon storage in longleaf pine stands planted on marginal agricultural lands. Ecol. Appl. 12, 1276-1285. doi: 10.1890/1051-0761(2002)012[1276:SCACSI]2.0.CO;2

Masiello, C. A., Chen, Y., Gao, X., Liu, S., Cheng, H. Y., Bennett, M. R., et al. (2013). Biochar and microbial signaling: production conditions determine effects on microbial communication. Environ. Sci. Technol. 47, 11496-11503. doi: $10.1021 /$ es $401458 \mathrm{~s}$

McBeath, A. V., and Smernik, R. J. (2009). Variation in the degree of aromatic condensation of chars. Organ. Geochem. 40, 1161-1168. doi: 10.1016/j.orggeochem.2009.09.006

McDowell, W. H., and Likens, G. E. (1988). Origin, composition, and flux of dissolved organic carbon in the hubbard brook valley. Ecol. Monogr. 58, 177-195. doi: 10.2307/2937024

Mergel, A., Timchenko, A., and Kudeyarov, V. (1998). "Role of plant root exudates in soil carbon and nitrogen transformation," in Root Demographics And Their Efficiencies in Sustainable Agriculture, Grasslands and Forest Ecosystems: Proceedings of the 5th Symposium of the International Society of Root Research, Held 14-18 July 1996 At Madren Conference Center, Clemson University, Clemson, South Carolina, USA. ed J. E. Box (Dordrecht: Springer).

Mille-Lindblom, C., Von Wachenfeldt, E., and Tranvik, L. J. (2004). Ergosterol as a measure of living fungal biomass: persistence in environmental samples after fungal death. J. Microbiol. Methods 59, 253-262. doi: 10.1016/j.mimet.2004.07.010

Mukherjee, A., Zimmerman, A. R., Hamdan, R., and Cooper, W. T. (2014). physicochemical changes in pyrogenic organic matter (biochar) after 15 months of field aging. Solid Earth 5, 693-704. doi: 10.5194/se-5-693-2014

Nardi, S., Concheri, G., Pizzeghello, D., Sturaro, A., Rella, R., and Parvoli, G. (2000). Soil organic matter mobilization by root exudates. Chemosphere 41, 653-658. doi: 10.1016/S0045-6535(99)00488-9

Natelhoffer, K. J., and Fry, B. (1988). Controls on natural Nitrogen-15 and Carbon13 abundances in forest soil organic matter. Soil Sci. Soc. Am. J. 52, 1633-1640. doi: 10.2136/sssaj1988.03615995005200060024x

Norwood, M. J., Louchouarn, P., Kuo, L.-J., and Harvey, O. R. (2013). Characterization and biodegradation of water-soluble biomarkers and organic carbon extracted from low temperature chars. Organ. Geochem. 56, 111-119. doi: 10.1016/j.orggeochem.2012.12.008

Novak, J. M., Busscher, W. J., Laird, D. L., Ahmedna, M., Watts, D. W., and Niandou, M. A. S. (2009). Impact of biochar amendment on fertility of a southeastern coastal plain soil. Soil Sci. 174, 105-112. doi: 10.1097/SS.0b013e3181981d9a

O'Neill, B., Grossman, J., Tsai, M. T., Gomes, J. E., Lehmann, J., Peterson, J., et al. (2009). Bacterial community composition in brazilian anthrosols and adjacent soils characterized using culturing and molecular identification. Microb. Ecol. 58, 23-35. doi: 10.1007/s00248-009-9515-y

Qualls, R. G., and Haines, B. L. (1991). Geochemistry of dissolved organic nutrients in water percolating through a forest ecosystem. Soil Sci. Soc. Am. J. 55, 1112-1123. doi: 10.2136/sssaj1991.03615995005500040036x

R-Core Team (2017). R: A Language And Environment For Statistical Computing. Available online at: https://www.R-Project.Org/ (Accessed January 29, 2018).

Raimbault, P., Pouvesle, W., Diaz, F., Garcia, N., and Sempéré, R. (1999). WetOxidation and automated colorimetry for simultaneous determination of 
organic carbon, nitrogen and phosphorus dissolved in seawater. Mar. Chem. 66, 161-169. doi: 10.1016/S0304-4203(99)00038-9

Rajkovich, S., Enders, A., Hanley, K., Hyland, C., Zimmerman, A. R., and Lehmann, J. (2012). Corn growth and nitrogen nutrition after additions of biochars with varying properties to a temperate soil. Biol. Fertil. Soils, 48, 271-284. doi: 10.1007/s00374-011-0624-7

Reisser, M., Purves, R. S., Schmidt, M. W. I., and Abiven, S. (2016). Pyrogenic carbon in soils: a literature-based inventory and a global estimation of its content in soil organic carbon and stocks. Front. Earth Sci. 4:80. doi: 10.3389/feart.2016.00080

Richardson, A. E., Lynch, J. P., Ryan, P. R., Delhaize, E., Smith, F. A., Smith, S. E., et al. (2011). Plant and microbial strategies to improve the phosphorus efficiency of agriculture. Plant Soil 349, 121-156. doi: 10.1007/s11104-011-0950-4

Santin, C., Doerr, S. H., Preston, C. M., and Gonzalez-Rodriguez, G. (2015). Pyrogenic organic matter production from wildfires: a missing sink in the global carbon cycle. Glob. Change Biol. 21, 1621-1633. doi: 10.1111/gcb.12800

Sarkhot, D. V., Berhe, A. A., and Ghezzehei, T. A. (2012). Impact of biochar enriched with dairy manure effluent on carbon and nitrogen dynamics. J. Environ. Qual. 41, 1107-1114. doi: 10.2134/jeq2011.0123

Schmidt, M. W. I., and Noack, A. G. (2000). Black carbon in soils and sediments: analysis, distribution, implications, and current challenges. Global Biogeochem. Cycles 14, 777-793. doi: 10.1029/1999GB001208

Shaw, J. N., West, L. T., Bosch, D. D., Truman, C. C., and Leigh, D. S. (2004). Parent material influence on soil distribution and genesis in a paleudult and kandiudult complex, southeastern USA. Catena 57, 157-174. doi: 10.1016/j.catena.2003.10.016

Shi, R. Y., Hong, Z. N., Li, J. Y., Jiang, J., Baquy, M. A., Xu, R. K., et al. (2017). Mechanisms for increasing the ph buffering capacity of an acidic ultisol by crop residue-derived biochars. J. Agric. Food Chem. 65, 8111-8119. doi: 10.1021/acs.jafc.7b02266

Shi, R. Y., Li, J. Y., Jiang, J., Kamran, M. A., Xu, R. K., and Qian, W. (2018). Incorporation of corn straw biochar inhibited the re-acidification of four acidic soils derived from different parent materials. Environ. Sci. Pollut. Res. doi: 10.1007/s11356-018-1289-7

Skjemstad, J. O., Reicosky, D. C., Wilts, A. R., and McGowan, J. A. (2002). Charcoal carbon in, U.S. agricultural soils. Soil Sci. Soc. Am. J. 66, 1249-1255. doi: $10.2136 /$ sssaj2002.1249

Skjernstad, J. O., Taylor, J. A., and Smernik, R. J. (1999). Estimation of charcoal (Char) in soils. Commun. Soil Sci. Plant Anal. 30, 2283-2298. doi: 10.1080/00103629909370372

Soil Survey Staff (2018). Natural Resources Conservation Service, United States Department of Agriculture. Web Soil Survey. Available online at: https:// Websoilsurvey.Sc.Egov.Usda.Gov/ (Accessed April 14, 2018).

Sorrenti, G., Masiello, C. A., Dugan, B., and Toselli, M. (2016). Biochar physicochemical properties as affected by environmental exposure. Sci. Tot. Environ. 563-564, 237-246. doi: 10.1016/j.scitotenv.2016.03.245
Spokas, K. A., Novak, J. M., and Venterea, R. T. (2012). Biochar's role as an alternative n-fertilizer: ammonia capture. Plant Soil, 350, 35-42. doi: 10.1007/s11104-011-0930-8

Steinbeiss, S., Gleixner, G., and Antonietti, M. (2009). Effect of biochar amendment on soil carbon balance and soil microbial activity. Soil Biol. Biochem. 41, 1301-1310. doi: 10.1016/j.soilbio.2009. 03.016

Steiner, C., Glaser, B., Geraldes Teixeira, W., Lehmann, J., Blum, W. E. H., and Zech, W. (2008). Nitrogen retention and plant uptake on a highly weathered central amazonian ferralsol amended with compost and charcoal. J. Plant Nutrit. Soil Sci. 171, 893-899. doi: 10.1002/jpln.2006 25199

Sung, S.-J. S., White, L. M., Marx, D. H., and Otrosina, W. J. (1995). Seasonal ectomycorrhizal fungal biomass development on loblolly pine (Pinus Taeda, L.) seedlings. Mycorrhiza 5, 439-447.

Wallander, H., Mörth, C.-M., and Giesler, R. (2009). Increasing abundance of soil fungi is a driver for $15 \mathrm{n}$ enrichment in soil profiles along a chronosequence undergoing isostatic rebound in northern sweden. Oecologia 160, 87-96. doi: 10.1007/s00442-008-1270-0

Wang, G., Jia, Y., and Li, W. (2015). Effects of environmental and biotic factors on carbon isotopic fractionation during decomposition of soil organic matter. Sci. Rep. 5:11043. doi: 10.1038/srep11043

Wang, J., Xiong, Z., and Kuzyakov, Y. (2016). biochar stability in soil: metaanalysis of decomposition and priming effects. GCB Bioenergy 8, 512-523. doi: $10.1111 /$ gcbb.12266

Wang, T., Arbestain, M. C., Hedley, M., Singh, B. P., Calvelo-Pereira, R., and Wang, C. (2014). Determination of Carbonate-C in biochars. Soil Res. 52, 495-504. doi: 10.1071/SR13177

Yao, F. X., Arbestain, M. C., Virgel, S., Blanco, F., Arostegui, J., MaciáAgull,ó, J. A., et al. (2010). Simulated geochemical weathering of a mineral Ash-Rich biochar in a modified soxhlet reactor. Chemosphere 80, 724-732. doi: 10.1016/j.chemosphere.2010.05.026

Zimmerman, A. R. (2010). Abiotic and microbial oxidation of laboratoryproduced black carbon (Biochar). Environ. Sci. Technol. 44, 1295-1301. doi: $10.1021 /$ es 903140 c

Conflict of Interest Statement: The authors declare that the research was conducted in the absence of any commercial or financial relationships that could be construed as a potential conflict of interest.

Copyright (C) 2018 Stuart, Anderson, Lazzarino, Kuehn and Harvey. This is an openaccess article distributed under the terms of the Creative Commons Attribution License (CC BY). The use, distribution or reproduction in other forums is permitted, provided the original author(s) and the copyright owner are credited and that the original publication in this journal is cited, in accordance with accepted academic practice. No use, distribution or reproduction is permitted which does not comply with these terms. 